\title{
Normal and Physio-Pathological Striatal Dopamine Homeostasis
}

\author{
Vincent Leviel1,2,3, Alain Gobert ${ }^{1}$, Valérie Olivier ${ }^{1}$, \\ Christine Dentresangle ${ }^{2}$, Wadad Hassoun ${ }^{2}$ and Kwamivi Dzahini ${ }^{3}$ \\ ${ }^{1}$ CNRS, IAF, 91198 Gif sur Yvette, \\ ${ }^{2}$ CNRS, UMR 5542, Lyon \\ IINSERM, U846, SBRI, Bron,
}

France

\section{Introduction}

The neurotransmitter Dopamine (DA) exerts a dual function in the striatum (STR), the latter comprising the caudate and putamen nuclei, the main structures in the central nervous system from which it is released. During the last 50 years, numerous studies have highlighted the role of DA in sensory/motor loops. Along with a phasic function exerted in synaptic or close apposition structures, a modulatory role for extracellular DA has also been demonstrated based on the slow and tonic extracellular diffusion of the amine. This duality is probably supported by a metabolic polymorphism, particularly of the release mechanism. The present chapter focuses on works carried out in vivo over the last two decades on the control of DA homeostasis in the STR during normal and pathological conditions. It is now generally accepted that the level of extracellular DA is not simply the consequence of dribbling from the synapse after phasic (firing-dependent) overflow but is maintained through tonic, largely non-synaptic, regulatory processes.

The duality of DA release in vivo will first be described. An example of an experimental situation allowing this situation to be characterized will be given, followed by a brief overview of the relevant literature from the last three decades.

The tonic regulatory process remains incompletely understood and still requires thorough analysis. In recent years, in vivo and in vitro studies have led to the development of theoretical models based on the concept of the reversion of the well-known uptake mechanism involving the DA transporter protein (DAT). In particular conditions, DAT could be involved in the control of the extracellular DA concentration through its ability to perform what is called reverse DA transport (DA-RT). Psychotropes from the amphetamine family are known to induce the release of DA through this mechanism, but the physiological involvement of DA-RT has rarely been adressed.

A large number of regulatory processes have been described concerning tonic DA release. Only two aspects of these regulatory processes will be considered here. Specific experiments devoted to showing the role of DA synthesis and extracellular calcium ions will be described and discussed. 
The two first paragraphs will be devoted to the duality of normal DA neurotransmission. It is however crucial to understand how the two different mechanisms of release (tonic and phasic) could maintain their equilibrium in pathological situations. Numerous animal models of neurodegeneration have been created. To date, only situations mimicking the early phases of parkinsonian neurodegeneration have been used to explore this equilibrium. Original results will also be presented here. These will provide new information on the regulatory modulation of the tonic and phasic release occurring during the initial presymptomatic compensatory phases of Parkinson's disease.

\section{The dual DA release process}

The extracellular DA concentration in the caudate nucleus could be relevant to something other than the electrical activity of dopaminergic cells. Increased DA release was even observed in the STR under experimental conditions that decreased cell firing in the substantia nigra (SNc, Romo et al., 1986). Since the first proposal by Raiteri et al. (1977) that DA could be released by a calcium-independent and carrier-mediated process, numerous authors have claimed that the firing-dependent release of DA does not explain all the reported alterations in the extracellular DA concentration and that an additional release mechanism must exist (Liang and Rutledge, 1982; Parker and Cubeddu, 1986; Vizi and Labos, 1991). In 1991, A. Grace gathered relevant data and proposed the presence of two modes of release of the amine in the STR (Fig 1), one 'phasic', taking place within the millisecond range, and controlled by The firing running on DA axons, and a 'tonic' mode, taking place over minutes or hours and mainly dependent on various direct influences on the DA terminals including that of Glutamate (GLU). Using differential pulse amperometry (DPA) simultaneously associated with local superfusion and HPLC detection we observed this dual release of DA in response to axonal stimulation and the application of GLU agonists (Fig. 2; Olivier et al., 1995).

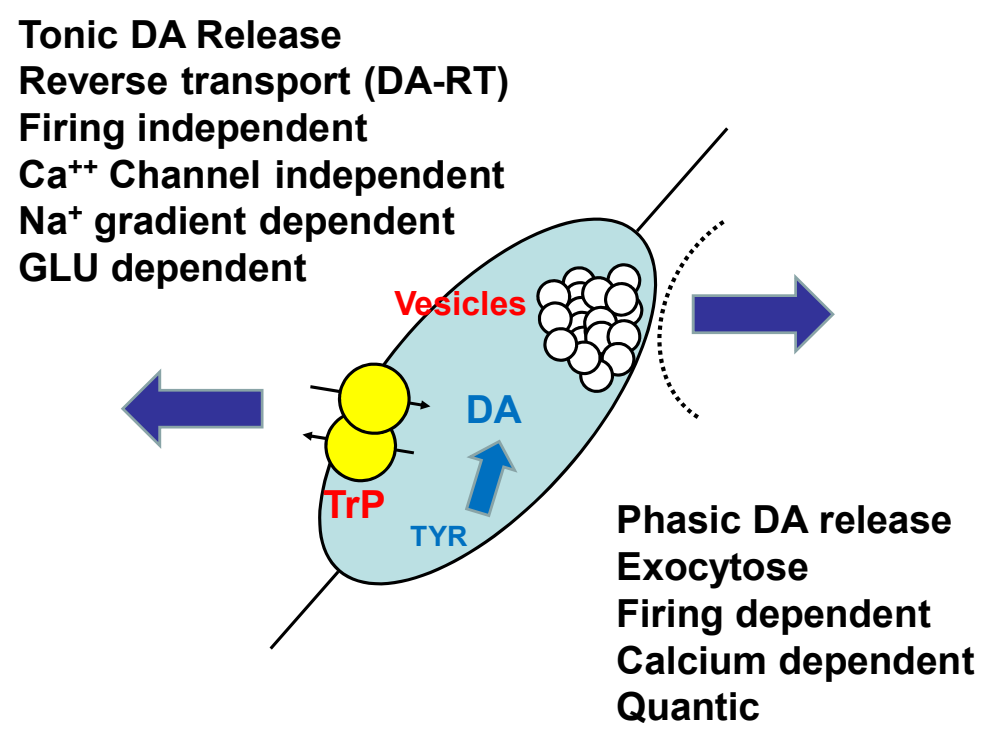

Fig. 1. The dual release of DA through vesicles exocytose or DA transport $(\operatorname{TrP})$. 


\subsection{Spontaneous and evoked DA release}

Dual release can be demonstrated by the simultaneous use of two probes. DPA uses a carbon fiber electrode to detect the DA released following stimulation of the DA axons in the Medial Forebrain Bundle (MFB) in the lateral hypothalamus. Every 4 minutes, a 20second stimulation-train pulse produces a large increase in the amperometric signal in the STR that is strictly restricted to the stimulation period (Fig. 2, Olivier et al., 1995). The amplitude of the peaks that occur is roughly constant over time. As discussed elsewhere by Gonon (1988) and Suaud-Chagny et al. (1992), the increase in the oxidation current under these conditions is likely to be mainly due to the DA released, despite the fact that some of this increase could be due to dihydroxyphenyl acetic acid (DOPAC), the first DA metabolite. Simulation of the MFB alters the differential oxidation current but is ineffective in terms of the amount of regional extracellular basal DA measured through a cannula close to the probe used for DPA. The DA collected through the superfusion system originates from a region considerably larger than the carbon fiber. The carbon fiber is only sensitive to events occurring in the range of $\mu \mathrm{m}$ from its suface whereas the superfusing probe collects diffusing molecules from within several hundreds of microns. Differences also arise from the duration of the measurements. Stimulation of the MFB only lasts for a short period of the collection time (here $0.08 \%$ ). Given this short period of time, any increase in the release of the amine remains undetectable in the superfusing fluid. The superfusing methods are particularly useful for detecting 'regional' fluctuations whereas voltammetry reports local events.

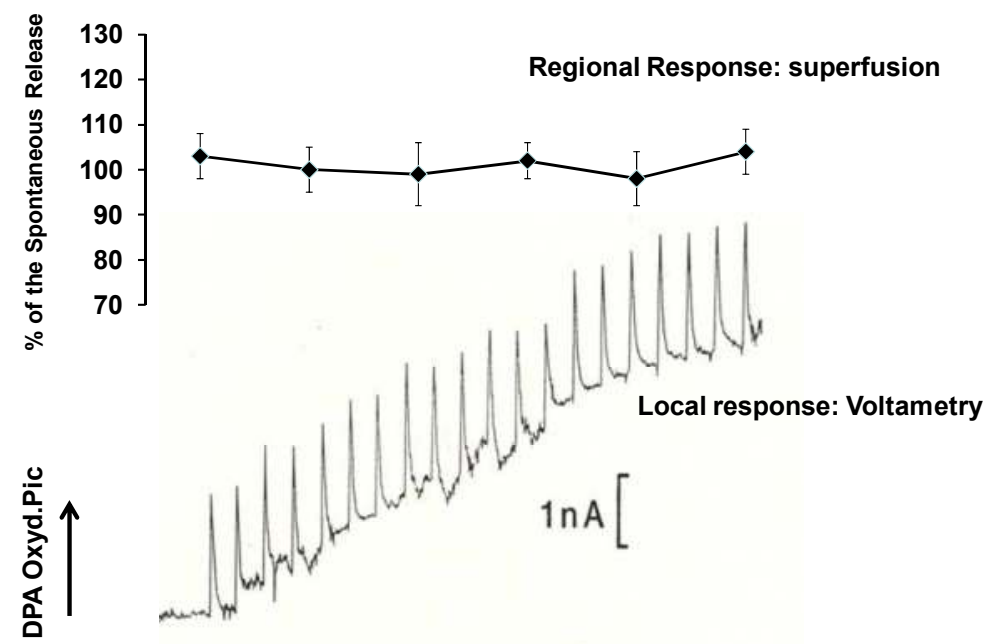

$20 \mathrm{sec}$ Pulses trains

Fig. 2. The effect of MFB stimulation on tonic (up) and phasic down DA release

Superfusion in the presence of cadmium ions: 
To block the voltage-dependent calcium channel, $100 \mu \mathrm{M}$ cadmium was added to the artificial LCR supplying the cannula. This treatment blocks the stimulation-evoked release of DA detected using DPA (Fig. 3). The same effect can be obtained using $1 \mathrm{mM}$ cobalt (not shown) in place of cadmium and remains unchanged in the presence of $0.5 \mu \mathrm{M}$ GBR12909, a DAT inhibitor. Surprisingly, in the presence of cadmium or cobalt the amount of DA detected in the superfusing fluid greatly increased during the first 40 minutes of application (Fig. 3). Over this period of time, the DA collected fell below control values. When $0.5 \mu \mathrm{M}$ GBR12909 was simultaneously added with cadmium, no further increase in the amount of DA was detected in the superfusing fluid.

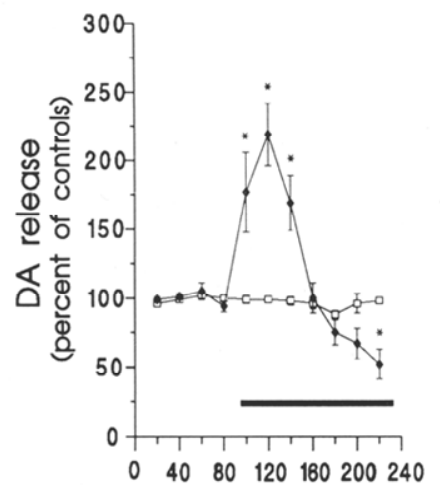

Min.

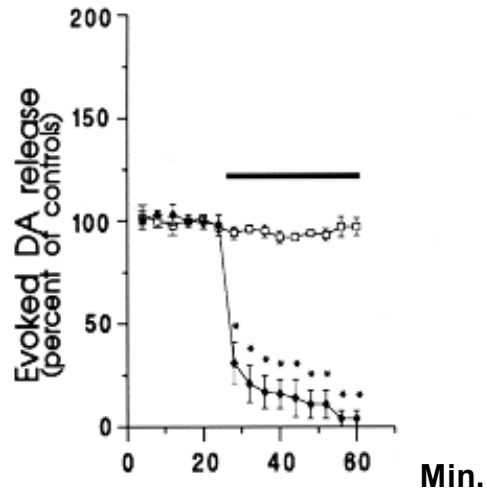

Min.

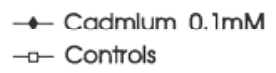

Fig. 3. Blockade of calcium channels via local application of cadmium

Local superfusion with GLU agonists:

Addition of the GLU agonists NMDA $(1 \mathrm{mM})$ and kainate $(0.1 \mathrm{mM})$ to the superfusing fluid increased the amount of DA collected through the push-pull cannula and reduced the amperometric signal evoked by MFB stimulations (Fig. 4). The reduction in the amperometric signal was not counteracted by the presence of $0.5 \mu \mathrm{M}$ GBR12909. In contrast the increase in the spontaneous release measured through the cannula in response to NMDA or Kainate application completely disappeared.

\subsection{From quantal release to reverse transport, the duality of DA release}

These experimental observations constitute the most simple and direct evidence of the presence of a double mechanism of release of DA from the DA terminals in the STR. A large set of complementary data will now be briefly reviewed.

Can DA homeostasis be regulated by the firing-evoked synaptic release of DA? 


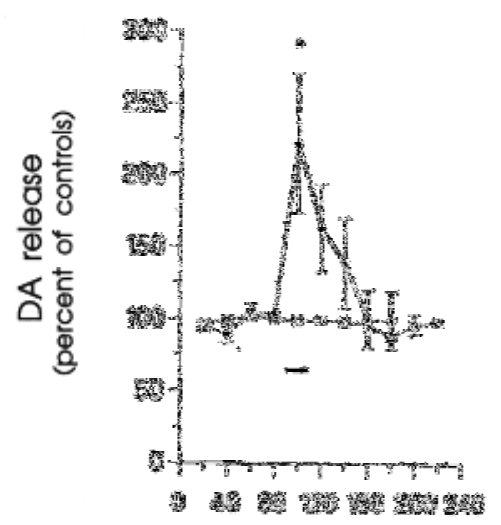

Min.

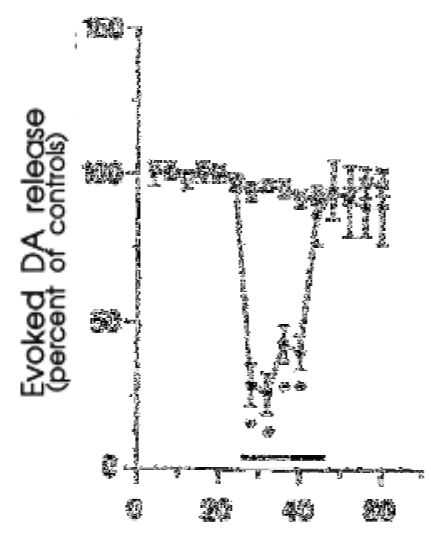

Min.

\section{- $\rightarrow$ - B

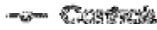

Fig. 4. The dual effect of GLU receptor blockade

The first evidence that regional extracellular DA and synaptic DA are not governed by the same mechanism is derived from the fact that although they should vary in parallel, that is clearly not the case. Many observations based on voltammetry have confirmed the ability of DA axons transiting through the MFB to carry an electrical potential, since an increase in extracellular DA can occur in response to electrical stimulations of the MFB (see above, Ewing and Wightman, 1984; Ewing et al., 1983; Gonon and Buda, 1985; Kuhr et al., 1986; Stamford et al., 1986). The voltammetric approach can only be used in a very restricted region of the space due to the size of the probes used. When using methods suitable for larger regions (microdialysis, push-pull cannula systems), it became clear that to alter DA levels in the STR, stimulation of the DA afferents required axonal recruitment and stimulation frequencies outside the physiological range (Grace, 1991; Olivier et al., 1995). Indeed, more than $60-70 \%$ of DA varicosities were found to be asynaptic, and DA synapses represent only about $1.8-7 \%$ of all striatal synapses (Decarries and Mechawar, 2000). Even if DA cell firing can elicit DA release in the STR for a brief period of time, the synaptic DA released may not be the only contributor to extracellular DA levels and would not be expected to be responsible for homeostatic DA control in the STR (Grace, 1991; Levi and Raiteri, 1993; Olivier, 1995). DA concentration is probably only partially monitored by nigral DA firing cells and DA homeostasis is unlikely to be controlled by spill-over of the amine from synaptic events.

\section{Using DAT to re-visit DA release: DA-RT}

It has been known for many years that exocytosis is not the only outward process of the neurotransmitter exchange between neurons and the extracellular space (Stein, 1967). Regarding monoamines, several models in the peripheral nervous system have been proposed that are generally based on exchange diffusion (Bogdanski and Brodie, 1969; Paton 1973a, 1973b). Concerning the release of DA in the central nervous system, DAT was thought to be partly involved in DA release by some authors (Marchi et al., 1985; Olivier et al., 1995; Raiteri et al., 1979) and the mechanism of this carrier-mediated release came from 
observations on psychostimulants and amphetamine-like substances (Butcher et al., 1988; Fisher and Cho, 1979; Leviel, 2001; Levi and Raiteri, 1993; Nash and Brodkin, 1991). In this process, transmitter molecules are transported outside the cell, most likely via an exchangediffusion process. This mode of transfer has been extensively studied and various mathematical models have been proposed over the course of the last four decades (Chubb et al., 1972; Stein, 1990, for a review; Thoenen et al., 1969; Wheeler et al., 1993; Ziance and Rutledge, 1972).

During the 1980s, several studies were devoted to the regulatory mechanism of DA release in the STR and the substantia nigra pars reticulate (SNr). Particular attention was given to the control of striatal release, which is known to be regulated by GLU. It appeared that, in addition to a spike-mediated DA efflux, GLU-induced amine overflow could occur independently of any sodium or calcium transfer. This would mean that some of the extracellular DA, the NMDA-mediated DA that is released, is not dependent on the firing of DA neurons (Carter et al., 1988; Cheramy et al., 1986; Giorguieff et al., 1977; Jhamandas and Marien, 1987). The NMDA-mediated release of DA even remained unchanged when the nigrostriatal pathway was blocked with lesions or tetrodotoxin (Keefe et al., 1992, 1993). Recently, using voltammetry associated with electrochemical detection, the same type of observation was again reported (Borland and Michael, 2004). Such observations had already led Anthony Grace to propose, at the beginning of the 1990s, that DA could be released in the STR following two different types of mechanism (Grace, 1991): first, the firingdependent exocytosis of quantal amounts of amine previously stored in specific pools, and, simultaneously, NMDA-mediated release.

More recently, Falkenburger et al. (2001) confirmed the existence of DA-RT in slices from rat SNc. This explained at least part of the dendritic release of DA. The presence of the somatodendritic release of DA from the nigrostriatal cells has been known for many years (Cheramy et al., 1981) but the mechanism of this release was, and remains, an open question. As in the experiment conducted by Olivier and co-workers, the demonstration was based on the use of DAT inhibitors (GBR 12909, GBR 12935) that were able to block the GLU-induced release of DA. In a more recent study (Opazo et al., 2010), the voltammetric current corresponding to outward moving DA was increased by adding 1Aminocyclopentane-trans 1,3 dicarboxylic acid (trans ACPD), an activator of the GLU group I mGLUR, to rat nigral slices. This confirmed the role of GLU in this type of DA release. It was also demonstrated that protein kinase $\mathrm{C}(\mathrm{PKC})$ activation produced a robust increase in external DA levels that was reversibly inhibited by GBR 12935, a well-known DAT inhibitor. These observations confirmed the identities of the two DA releasing processes. These observations were also made in vitro in an engineered neuroblastoma cell line (SH-SY5Y cells) stably expressing DAT (Opazo et al., 2010).

The two release processes act simultaneously in both the SNc and the dSTR. As mentioned above, and given the various morphologies of DA neurons (Arluison et al., 1978; Gauthier et al., 1999; Gerfen et al., 1987; Prensa et al., 2000), the possibility that some types of DA neurons could be specialized in one or the other of the release modes cannot be excluded. For instance, it is noteworthy that mesencephalic DA neurons from the ventral tegmental area poorly express DAT (Blanchard et al., 1994; Ciliax et al., 1999; Mengual and Pickel, 2004; Nirenberg et al., 1996; Sesack et al., 1998). The dual release function of DA neurons may not be equally distributed throughout the whole population of DA cells. The term 
'volume transmission', developed in the 1980s (Agnati et al., 1986) and recently used to characterize DA neurotransmission, does not refer to a mode of release but rather to a mode of extracellular transmission. The terms 'phasic release' and 'tonic release' most frequently refer to the pattern of discharge of the DA axons (regular or bursting). The most appropriate terms that have emerged to date to qualify the present types of neurotransmitter release are 'quantal' for the firing-dependent process and 'reverse transport' (DA-RT) or 'lateral release' for the carrier-mediated mechanism. We also use the term 'lateral release' to refer to the non-synaptic localization of this mechanism, due to the extra-synaptic position of the DA transporter. In this case, 'axial release' could refer to synaptic transmission.

\section{Regulatory mechanisms}

It has already been shown that the extracellular level of calcium $\left(\mathrm{Ca}^{++}\right)$ions has an important influence on neurotransmitter release (Katz and Miledi, 1970; Augustine et al., 1987; Smith and Augustine, 1988; Mulkey and Zucker, 1991) and on enzyme activities (Kapatos and Zigmond, 1982; El Mestikawy et al., 1983; Haycock, 1993). Since transient increases in $\mathrm{Ca}^{++}$within nerve terminals are spatially restricted (Lipscombe et al., 1988; Meldolesi et al., 1988; Miller, 1991) it may be hypothesized that $\mathrm{Ca}^{++}$independently affects multiple processes within the different ultrastructural compartments of the nerve terminal. The metabolism and release of DA in the STR constitute an appropriate experimental model with which to investigate the potentially distinct effects of $\mathrm{Ca}^{++}$. In the dopaminergic neurons DA synthesis depends on the activity of tyrosine hydroxylase (TH), the rate-limiting enzyme in its synthetic pathway (Levitt et al., 1965). This enzyme is activated by phosphorylation under the control of various protein kinases, including two $\mathrm{Ca}^{++}$-dependent ones, the $\mathrm{Ca}^{++}$-phospholipid-dependent protein kinases (PKC) and the $\mathrm{Ca}^{++}$-calmodulin-dependent protein kinase (PKII) (El Mestikawy et al., 1983; Albert et al., 1984; Zigmond et al., 1989; Haycock, 1993).

Below we will present further data about the dual control exerted by $\mathrm{Ca}^{++}$ions on DA synthesis and on DA-releasing processes. The apparent challenge between synthesis and release in the effects of $\mathrm{Ca}^{++}$is coming from the fact that DA-RT acts on cytoplasmic DA, unlike exocytosis, which affects a previously vesicularysed stored pool of DA. It can thus be hypothesizd that DA-RT should be more sensitive to those treatments affecting synthesis.

\subsection{Synthesis, calcium ions and DA release - Experimental report}

We describe here the only method known to evaluate DA synthesis and release simultaneously in vivo in anesthetized rats. The method is based on the measurement of the specific activity $\left(\mathrm{DA}_{\mathrm{sa}}\right)$ of the DA released during continuous superfusion of the tissue with the tritiated DA precursor, $\left[{ }^{3} \mathrm{H}\right]$ tyrosine. It was previously observed that the neosynthesized amine is released preferentially to an oldly stored pool. Taking advantage of this metabolic specificity, it can be postulated that: 1) increased $\mathrm{DA}_{s a}$ during higher levels of release reflects enhanced synthesis and 2) decreased $\mathrm{DA}_{s a}$ associated with increased levels of release reveals the involvement of stored amine (vesicular) and suggests reduced or insufficient synthesis. The DOPAC efflux is also considered to be a robust index of DA synthesis (Zetterström et al., 1988; Leviel et al., 1989). In other words, any treatment reducing synthesis should reduce cytoplasmic $\mathrm{DA}_{s a}$ and the DOPAC efflux. In contrast, any treatment activating synthesis should elevate $\mathrm{DA}_{s a}$ and the DOPAC efflux. 

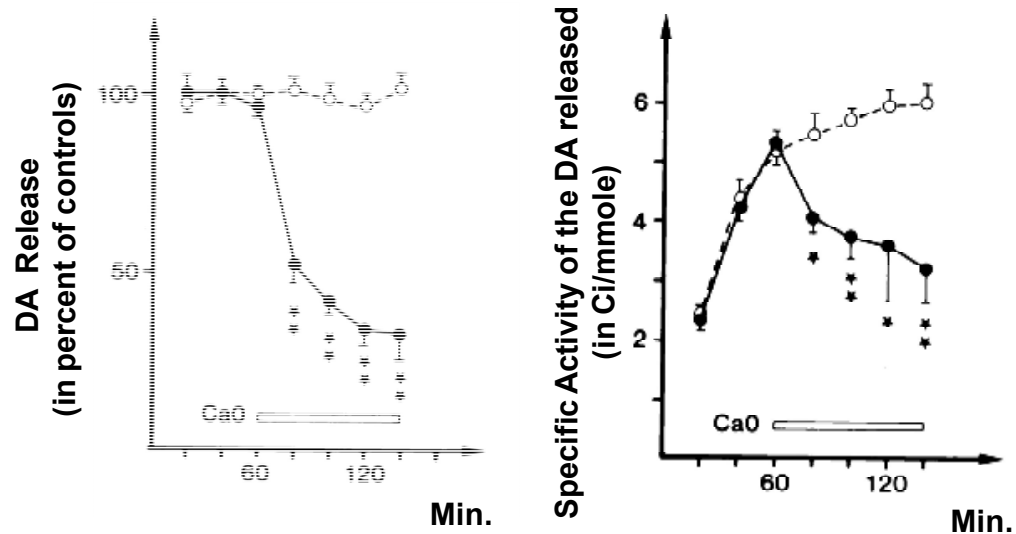

Fig. 5. Superfusion with CSF from which $\mathrm{Ca}^{++}$was omitted

Superfusion with calcium-free medium and a-methyl para-tyrosine (a-mpt)

We already know that local superfusion with the calcium channel blockers cadmium and cobalt enhances regional DA release and blocks firing-induced exocytosis. Removing $\mathrm{Ca}^{++}$ ions from the superfusing medium $(\mathrm{Ca} 0)$ led to a sharp decrease in DA release, stabilizing at around $30 \%$ of the basal value after about $80 \mathrm{~min}$. This effect was accompanied by a lowering of the specific activity of $\mathrm{DA}_{s a}$ and of [ $\left.{ }^{3} \mathrm{H}\right] \mathrm{DOPAC}$ (Fig. 5). The addition of a-mpt, a $\mathrm{TH}$ inhibitor, did not modify the effect of $\mathrm{Ca} 0$ treatment: the DA collected in each 20-minute fraction also stabilized at around $30 \%$ of the spontaneous values (Fig. 6). These two effects were thus not additive, and the lowering of the $\mathrm{DA}_{\text {sa }}$ produced by superfusion with $\mathrm{Ca} 0$ was of the same amplitude as that observed in the a-mpt treatment. This observation strongly suggests that the main effect of $\mathrm{Ca} 0$ could be the inhibition of DA synthesis (Olivier et al., 1999).

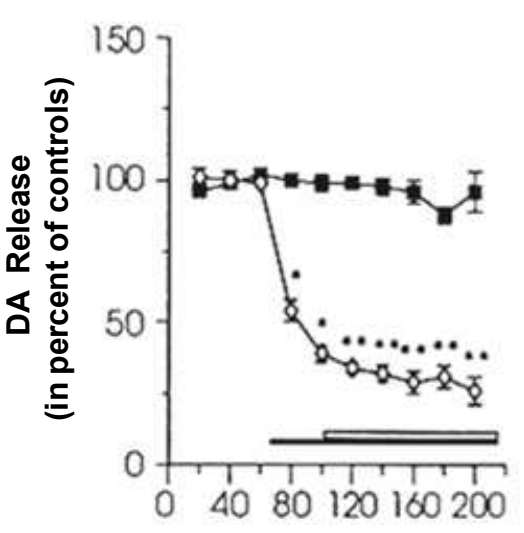

Min.

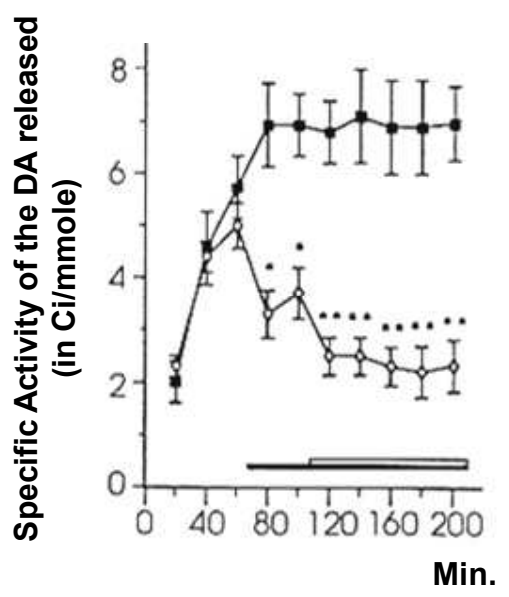

Fig. 6. The inhibition of DA synthesis during superfusion in the absence of $\mathrm{Ca}^{++}$ 
Superfusion with calcium ionophore (A23187): The forced entry of calcium

Adding the $\mathrm{Ca}^{++}$ionophore A23187 $(1 \mu \mathrm{mol} / \mathrm{l})$ to the superfusing fluid for $20 \mathrm{~min}$ had no effect on the spontaneous release of DA or DAsa (Fig. 7). However, an increase in DOPAC $(25 \%)$ was associated with a $50 \%$ increase in the [ $\left.{ }^{3} \mathrm{H}\right] \mathrm{DOPAC}$ concentration.

It is possible to evaluate the effect of the calcium ionophore A23187 on DA synthesis 'in vivo'. A high dose of amphetamine can be superfused to produce the maximum overflow of the intraterminal DA. Thus 1 hour after administering $20 \mathrm{~min}$ of $1 \mathrm{mmol} / \mathrm{l}$ amphetamine, the total intraterminal DA had increased, particularly the $\mathrm{DA}_{s a}$ (Olivier et al., 1999). This demonstrates a large increase in synthesis during this period of time.
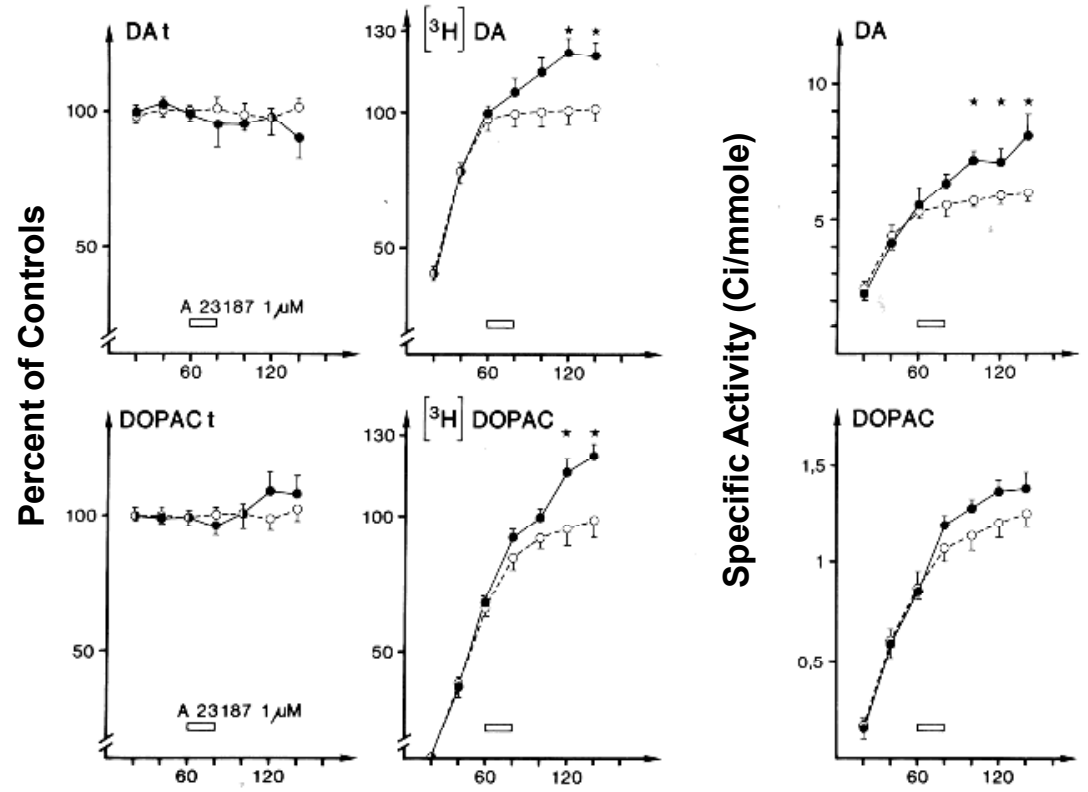

Time (Min.)

Fig. 7. Superfusion with the Ca ionophore A23187 increases DA synthesis and DOPAC efflux

\subsection{The effect of extracellular calcium ions on DA-RT}

The above observations confirm that $\mathrm{Ca}^{++}$ions are involved in different steps of DA metabolism, including not only the processes of release (Augustine et al., 1987) but also synthesis (Kapatos and Zigmond, 1982; El Mestikawy et al., 1983; Haycock et al., 1984). We have not directly measured the enzymatic activity of $\mathrm{TH}$, but alterations in synthesis were revealed by the dynamic variations in $\mathrm{DA}_{s a}$ and the $\left[{ }^{3} \mathrm{H}\right] \mathrm{DOPAC}$ efflux. Indeed the $\mathrm{DA}_{\mathrm{sa}} \mathrm{can}$ be used as an index of DA synthesis (Herdon et al., 1985) since the newly synthesized DA has a higher specific activity than the stored amine (Leviel et al., 1989). [ $\left.{ }^{3} \mathrm{H}\right]$ DOPAC might also be considered as a good index of amine synthesis according to many authors (Herdon 
et al., 1985; Soares-Da-Silva, 1987; Zetterström et al., 1988; Leviel et al., 1989; Soares-Da-Silva and Garrett, 1990a, 1990b), who have proposed that extracellular DOPAC originates from an unreleased and recently synthesized pool of dopamine.

$\mathrm{Ca}^{++}$ions in the regulation of DA synthesis:

Removal of $\mathrm{Ca}^{++}$from the superfusing fluid induced a large decrease in $\mathrm{DA}_{s a}$ and in $\left[{ }^{3} \mathrm{H}\right]$ DOPAC efflux, suggesting reduced DA synthesis. Futhermore the addition of a TH inhibitor, namely a-mpt, to a Ca+e ${ }^{++}$-free superfusing fluid did not further decrease the $\mathrm{DA}_{s a}$ or the $\left[{ }^{3} \mathrm{H}\right] \mathrm{DOPAC}$, suggesting that the activity of $\mathrm{TH}$ is already maximally inhibited by $\mathrm{Ca}^{++}$removal. TH activity could be inhibited by a rise in DA feedback inhibition resulting from the lowering of $\mathrm{Ca}^{++}$-dependent exocytosis (Leslie et al., 1985; Zucker and Lando, 1986; Westerink et al., 1988). However, the intracellular accumulation of DA should result in increased DOPAC efflux, which was not observed. Conversely, the reduced $\mathrm{DA}_{s a}$ revealed that even to maintain a low rate of DA release, stored amine (with a low specific activity) has to be involved, showing that in the absence of extracellular calcium ions, DA synthesis is unable to sustain the lower DA release ( $30 \%$ of the control value).

Superfusion without $\mathrm{Ca}^{++}$in the CSF appears to be able to reduce synthesis. Forced $\mathrm{Ca}^{++}$ entry could have the opposite effect. Indeed a low dose of the $\mathrm{Ca}^{++}$ionophore A23187 (1 $\mu \mathrm{mol} / \mathrm{l})$ slightly increased $\left[{ }^{3} \mathrm{H}\right] \mathrm{DA}$ and $\left[{ }^{3} \mathrm{H}\right]$ DOPAC efflux, suggesting an increase in DA synthesis (Fig. 7). Such activation of synthesis was confirmed by the potentiation of the amphetamine-induced [ $\left.{ }^{3} \mathrm{H}\right] \mathrm{DA}$ release that followed pretreatment with A23187 $1 \mu \mathrm{mol} / \mathrm{l}$ (Olivier et al., 1999).

This set of simple data is consistent with the concept that moderate $\mathrm{Ca}^{++}$entry is positively coupled with DA synthesis and that its absence from the extracellular medium is negatively coupled with DA synthesis (Kapatos and Zigmond, 1982; El Mestikawy et al., 1983; Haycock et al., 1984).

$\mathrm{Ca}^{++}$ions in the regulation of DA-RT:

Surprisingly, in vivo blockade of the $\mathrm{Ca}^{++}$ion channel with $\mathrm{Cd}^{++}$ions activates DA-RT from the DA terminals, an effect that was inhibited by further application of GBR 12909, a DAT inhibitor. The mechanism by which $\mathrm{Cd}^{++}$affects DA-RT is not clear. For a long time, reversal of the $\mathrm{Na}^{+}$gradient was proposed to reverse DA transport (Roth et al., 1976; Amejddki-Chab et al., 1992; Levi and Raiteri, 1993; Okada et al., 1990). It was also proposed by Olivier et al. (1999) that $\mathrm{Cd}^{++}$indirectly alters DA-RT via $\mathrm{Na}^{+} / \mathrm{K}^{+}$ATPase activity, a hypothesis also proposed for the action of AMPh (Khoshbouei et al., 2003; Pal et al., 1993).

After applying a $\mathrm{Ca}^{++}$ionophore, A23187, DA synthesis increased. With the classical model used for DA-RT of an exchange diffusion process, it is clear that the cytosolic DA constitutes the direct substrate for internal DAT-sites, regardless of its affinity. Thus, from these experiments, and despite the fact that DA-RT can be considered as being firingindependent, many observations during the last decade have confirmed indirect calcium action on DA-RT (Fog et al., 2006; Gnegy et al., 2004; Kantor et al., 2001; Page et al., 2004).

Numerous reports highlight the role of $\mathrm{Ca}^{++}$in the amphetamine-dependent DA-RT. The $\mathrm{Ca}^{++}$chelator BAPTA-AM reduced amphetamine-induced DA efflux as measured by amperometry. A particularly interesting observation was that superfusion of rat striatal slices with $50 \mu \mathrm{M}$ BAPTA-AM suppressed the amphetamine-induced release of endogenous 
DA. However, the same treatment had no effect on basal DA in the absence of AMPh. These studies demonstrated that AMPh-induced and DAT-mediated currents producing substrate efflux require internal $\mathrm{Ca}^{++}$release from intracellular stores and that amphetamine can stimulate dopamine efflux by regulating cytoplasmic $\mathrm{Ca}^{++}$levels (Gnegy et al., 2004). It has also been shown that $\mathrm{Ca}^{++} /$calmodulin-dependent protein kinase-II (CaMKII) plays a key role in the amphetamine-mediated efflux of DA in heterologous cells and dopaminergic neurons. CaMKII binds to the distal $C$ terminus of DAT and co-localizes with DAT in dopaminergic neurons. The distal serines of the $\mathrm{N}$ terminus of DAT were phosphorylated by CaMKII in vitro and the mutation of these serines eliminated the stimulatory effects of CaMKIIa. A mutation of the DAT C terminus, impairing CaMKIIa binding, also impaired AMPh-induced DA efflux. Thus, it was suggested that the binding of CaMKIIa to the DAT C terminus facilitates phosphorylation of the DAT $\mathrm{N}$ terminus, which is responsible for the AMPh-induced dopamine efflux (Fog et al., 2006).

A non-amphetaminic effect of CaMKII was also reported. Pseudo-phosphorylation of the hDAT N-terminal serines (S/D mutation), which appear to be phosphorylated by CaMKII, is largely able to evoke the reverse transport of DA even in unclamped cells, i.e. at resting membrane potential. This showed that activation of this enzymatic system (DAT) constitutes a mechanism of release by itself, even in the absence of amphetamine or any exogenous trigger. CaMKII is the most abundant kinase in the brain and could play a role in the regulation of various neurotransmitters (Colbran et al., 2003; Griffith, 2004). It is well known that local increases in $\mathrm{Ca}^{++}$concentration and the CaMKII complex interact with the transduction of several neuronal signals, whether from DA neurotransmitters or not. Numerous proteins, such as the NR2B subunit of the NMDA receptor, could be involved in tonic release processes. It was recently proposed that tonic hyperactivity of the GLU afferents to the dopaminergic striatal terminals could maintain tonic-activated DA overflow in the rat STR following a 6-OHDA lesion of the SNc (Dzahini et al., 2010), and mechanisms such as those presently known to be evoked could be responsible for the effects observed. The same type of tonic hyperactivity could also be present in the mesencephalic region of the SNc. Sustained hypertonic GLU neurotransmission is often observed and reported in experimental and natural situations of neuro-degeneration, and could maintain secondary amine overflow without immediate consequences, but cause insidious degeneration.

The main finding of recent reports about the regulatory processes of the DAT protein is the complete dissociation between inward (uptake) and outward (release) efflux. Untill recently DAT was considered to be an exchange diffusion system with a stoichiometric equilibrium linking the two functions. It is now clear that this concept should be revisited and that the inward regulatory processes differ from the release mechanism.

In summary, three steps in DA metabolism occur to determine the extracellular DA concentration: synthesis, exocytosis and reverse transport (fig.8). Directly or indirectly, $\mathrm{Ca}^{++}$ ions modulate each of these. Thus carrier-mediated release (DA-RT) appears to be indirectly and negatively coupled with calcium entry, whereas synthesis and exocytosis are directly and positively coupled with $\mathrm{Ca}^{++}$entry.

\subsection{Intraterminal DA metabolism: From synthesis to release}

The observations presented here and the numerous reports about DA synthesis, storage and release have enabled the proposal of a general model of the striatal DA terminal in 
physiological conditions (Leviel et al., 1989). As mentioned above, components of this model may be attributed to different DA neurons. In the model presented in Fig. 8, a central pool of cytosolic DA constitutes the central point of the functional organization. Three input and four output routes are then described. The major way of supplying this central pool is via DA synthesis. A secondary supply mechanism could involve the intraterminal egress of DA from the vesicular storage pool. The third input comprises DA uptake transport.

The first and major output of cytoplasmic DA involves the formation of DOPAC by the MAO enzyme. The second use of cytoplasmic DA involves terminal overflow through DA-RT. A small proportion of the synthesized DA is vesicularized in a neosynthesized pool constituting the preferentially releasable compartment of the amine, and is released by exocytosis. Some of this vesicularized amine supplies a storage compartment (old stored DA).

This model takes into account the different mechanisms of DA release and DA metabolism that can be independently regulated. For example, reduced exocytotic release (by the blockade of calcium channels) can be accompanied by increased DA-RT, leading to an increase in extracellular amine. Thus even if the depolarization of DA axons is clearly responsible for exocytotic DA release, the preterminal influences could lead to secondary release that is differentially regulated, producing the paradoxical observations that are often reported (Leviel et al., 1989).

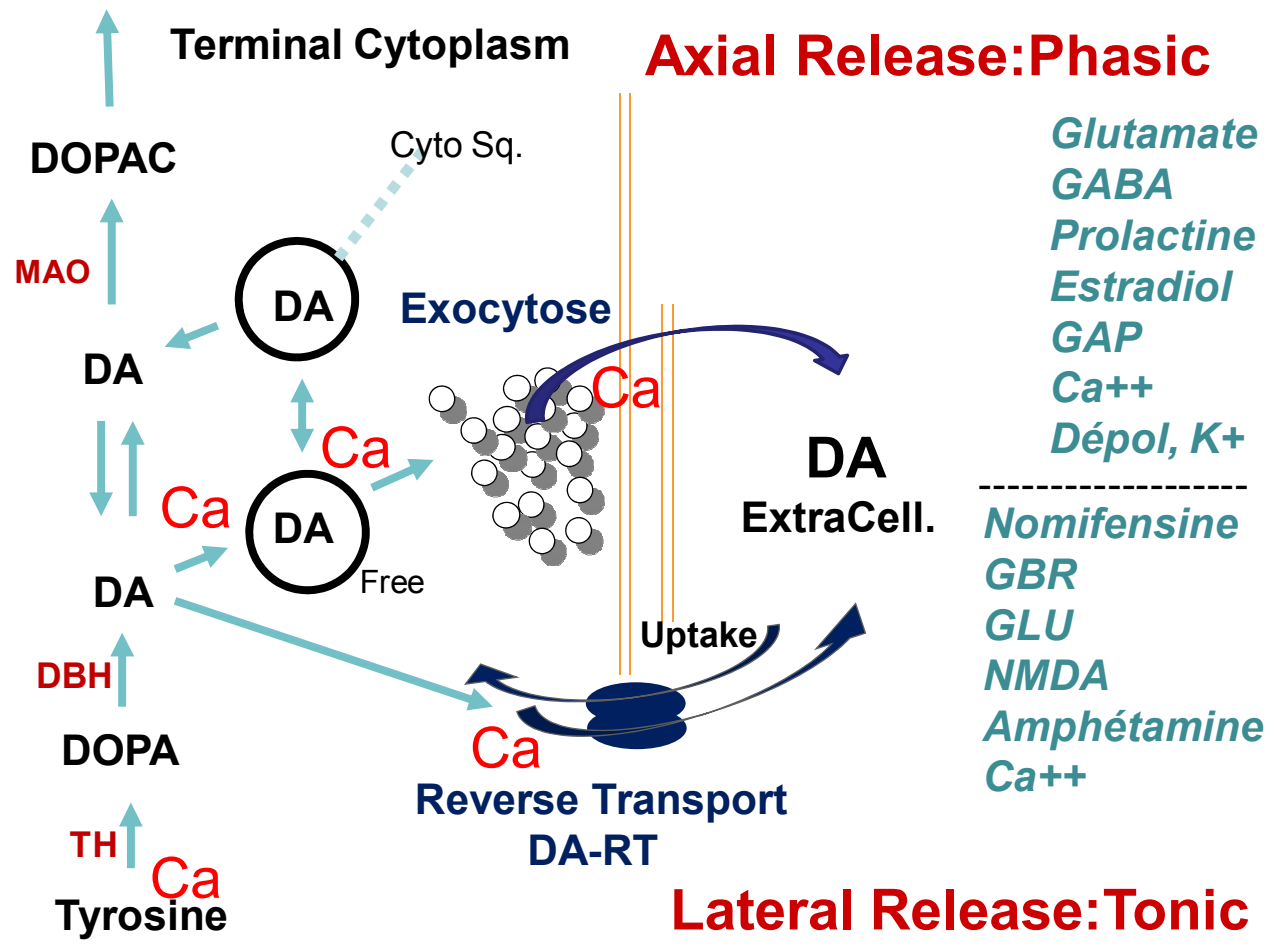

Fig. 8. The four-compartments model of intraterminal DA metabolism including dual release 


\section{Evolving DA release with DA cell degeneration}

\subsection{Progressive DA denervation of the STR enhances DA transport in synaptosomal preparations}

Why address the consequences of DA cell degeneration? So far we have described the equilibrium between two mechanisms that release DA, but only one of these is likely to be able to maintain DA homeostasis in the extracellular space. For a long time it was thought that the progressive degeneration of the DA cells of the $\mathrm{SN}$, such as observed in Parkinson'disease (PD), is accompanied by the preservation of the DA concentration in the STR, a region that is innervated by DA axons. Basic observations have ascertained that DA metabolism is activated in spared dopaminergic terminals of the partially denervated STR. Both increased DA synthesis and reduced storage capacity were recurrently reported (see Zigmond et al., 1990 for a review). This was considered to be the possible cause of the unmodified (or even sometimes increased) extracellular DA level in this region (Stackowiak et al., 1987; Altar and Marien, 1989; Espino et al., 1995; Dentresangle et al., 2001; Dzahini et al., 2010). Nevertheless, no changes in either the firing pattern or the efficacy of release were observed in nigral DA cells following a moderate partial lesion (Hollerman and Grace, 1990; Dentresangle et al., 2001). On the contrary, spared DA neurons were described as hypoactive and pre-apoptotic (Pasinetti et al., 1989). This adaptation is unlikely to be the result of the electrical hyperactivity of the surviving nigral DA cells.

Extracellular DA is taken up into dopaminergic terminals. In partially lesioned rats, the long-term reduction of this DA uptake may allow more diffusion in tissues (Snyder et al., 1990; van Horn et al., 1992; Gerhardt et al., 1996). This hypothesis is reinforced by the fact that the depolarization of cells bearing the DA transporter reduces their ability to take up extracellular amine (Roth et al., 1976; Zahniser et al., 1998). GLU neurotransmission could be involved in this process. Indeed GLU is responsible for tonic membrane depolarization in CP (Wilson et al., 1995) and GLU neurotransmission is known to be hyperactive following a partial lesion (Lindefors and Ungerstedt, 1990; Samuel et al., 1990; Iwasaki et al., 1992; Wullner et al., 1994).

Reduced DA uptake due to a reduced number of DA terminals is however unable to account for the maintained dopaminergic function as the extracellular DA concentration should also be correlated with a reduction in the number of release sites. No changes in the number of uptake sites per neuron were reported and the binding of the transporter ligands was even considered to be a good index of the terminal depopulation (Maloteaux et al., 1988; van Horne et al., 1992). Thus normal or increased levels of extracellular DA, associated with a reduced number of dopaminergic terminals, imply an increased release/uptake ratio per terminal. GLU neurotransmission in the STR may mediate this increase. GLU was reported to increase DA synthesis (Desce et al., 1992; Fillenz, 1993; Castro et al., 1996), to activate DA release (Giorguieff et al., 1977; Cheramy et al., 1986; Leviel et al., 1990; Keefe et al., 1992) and to reduce DA uptake (Lin and Chai, 1998). The mechanism by which basal DA release is altered is however poorly understood. In the absence of any change in DA cell activity, alterations should involve DA-RT. This concept of activation of the DA metabolism through local GLU-dependent activation of DA-RT from the striatal DA terminal in response to the DA cell depopulation is widely debated. The following paragraph addresses this problem by analyzing the results of experiments based on progressive or very partial lesions of the nigrostriatal DA pathway in the rat. 


\subsection{Experimental observations}

To address this issue, partial and progressive destruction of the dopaminergic terminals of the STR was achieved and various biochemical parameters were monitored. The injections were not directly located in the striatal tissue but in the lateral ventricle. Recurrent 6-OHDA injections were administered week after week, locally in the rat STR. In these lesioned rats, metabolic alterations of DA were followed along with the kinetic parameters of the uptake process in synaptosomal preparations. These parameters (apparent $\mathrm{Km}$ and Vmax) are correlated with the number of uptake sites determined in binding experiments with a ligand of the DAT carrier protein, GBR12935. The possible role of GLU neurotransmission in these alterations was also investigated.

Neither behavioral disturbance nor loss of weight was observed during treatment. Following successive injections, however, progressive biochemical alterations developed in both the median and lateral part of the STR, ipsilaterally to the injected ventricle.

Control values for tissue DA were $54.9 \pm 9.3 \mathrm{ng} / \mathrm{mg}$ prot and $45.7 \pm 6.9 \mathrm{ng} / \mathrm{mg}$ prot for the median and lateral STR respectively. For tissue DOPAC, the control values were $27.19 \pm 3.6$ $\mathrm{ng} / \mathrm{mg}$ prot and $26.4 \pm 4.11 \mathrm{ng} / \mathrm{mg}$ prot in the median and lateral STR respectively. The first changes observed were in tissue DA, which began to decrease after the first two injections, reaching only 23.3 and $29.6 \%$ (median and lateral STR respectively) of the values of the sham-injected animals after the 8th injection (Fig. 9). The decrease in tissue DOPAC was

\section{Medial Striatum}
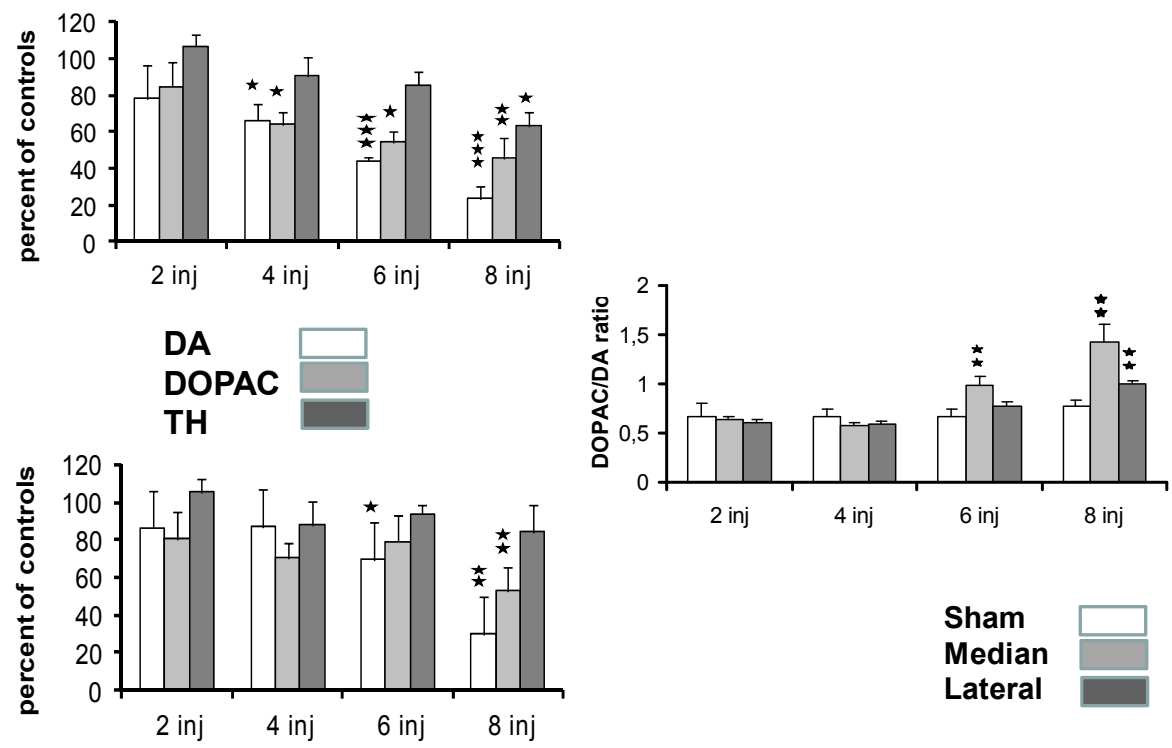

\section{Lateral Striatum}

Fig. 9. Tissue DA, DOPAC and TH (left). Mean TH activity indexed by DOPAC/DA ratio (Right). 
slower, reaching 45.5 and $52.7 \%$ (median and lateral STR respectively) of the controls after the 8 th injection. The tissue DOPAC/DA ratio (0.494 in the control rats) increased significantly only after the 6th injection, reaching a value of 1.4 in the median part of the STR after the 8th injection (Fig. 9). The tissue content of TH (Fig. 9) decreased very slowly and the differences compared with control rats $(8.94 \pm 0.60 \mathrm{UTH}$ in the median STR; $9.24 \pm 0.81$ UTH in the lateral STR) were only significant after the 8th injection (63 and $84.4 \%$ of controls in the median and lateral STR respectively). These alterations were first detected in the medial part of the STR (in the more lesioned part) and 2 weeks later, more laterally. Thus an immediate alteration of tissue DOPAC and DA was observed, followed by a delayed increase in the DOPAC/DA ratio and a late reduction in the amount of TH.

Binding of $[3 \mathrm{H}] \mathrm{GBR} 12935$ was measured in synaptosomes prepared from rats that heen injected for 8 weeks. The $B_{\max }$ in the sham-operated group was $3.82 \mathrm{pmole} / \mathrm{mg}$ prot. In the lesioned group, $B_{\max }$ fell to $2.31 \mathrm{pmole} / \mathrm{mg}$ prot $(60.4 \%)$ but returned to $3.42 \mathrm{pmole} / \mathrm{mg}$ prot in lesioned animals treated daily with MK801 (89.5\% of sham-operated group). The ability of synaptosomes to load [ $\left.{ }^{3} \mathrm{H}\right] \mathrm{DA}$ was not greatly affected in lesioned animals. The slopes of the $\left[{ }^{3} \mathrm{H}\right] \mathrm{DA}$ accumulation curves were: $0.101 \mathrm{pmole} / \mathrm{mg} \mathrm{prot} / \mathrm{min}$ for the sham-operated animals, $0.089 \mathrm{pmole} / \mathrm{mg}$ prot $/ \mathrm{min}$ for the lesioned group $(88.6 \%$ of the sham-operated group, n.s.) and $0.098 \mathrm{pmole} / \mathrm{mg}$ prot $/ \mathrm{min}$ for the lesioned animals treated with MK801 (97.1\% of the sham-operated group, n.s.) (Fig. 10). However, the ratio between $\left[{ }^{3} \mathrm{H}\right] \mathrm{DA}$ accumulation and [ $\left.{ }^{3} \mathrm{H}\right]$ GBR12935 binding (in pmol/pmol of $\left[{ }^{3} \mathrm{H}\right] \mathrm{GBR} 12935 / \mathrm{min}$, data not shown) was $0.026(100 \%)$ for the sham-operated animals, 0.038 for the lesioned group $(146.5 \%$; $\mathrm{P}<0.05)$ and 0.028 for the lesioned animals treated with MK801 $(108.5 \%$ of the sham-operated group, n.s.).

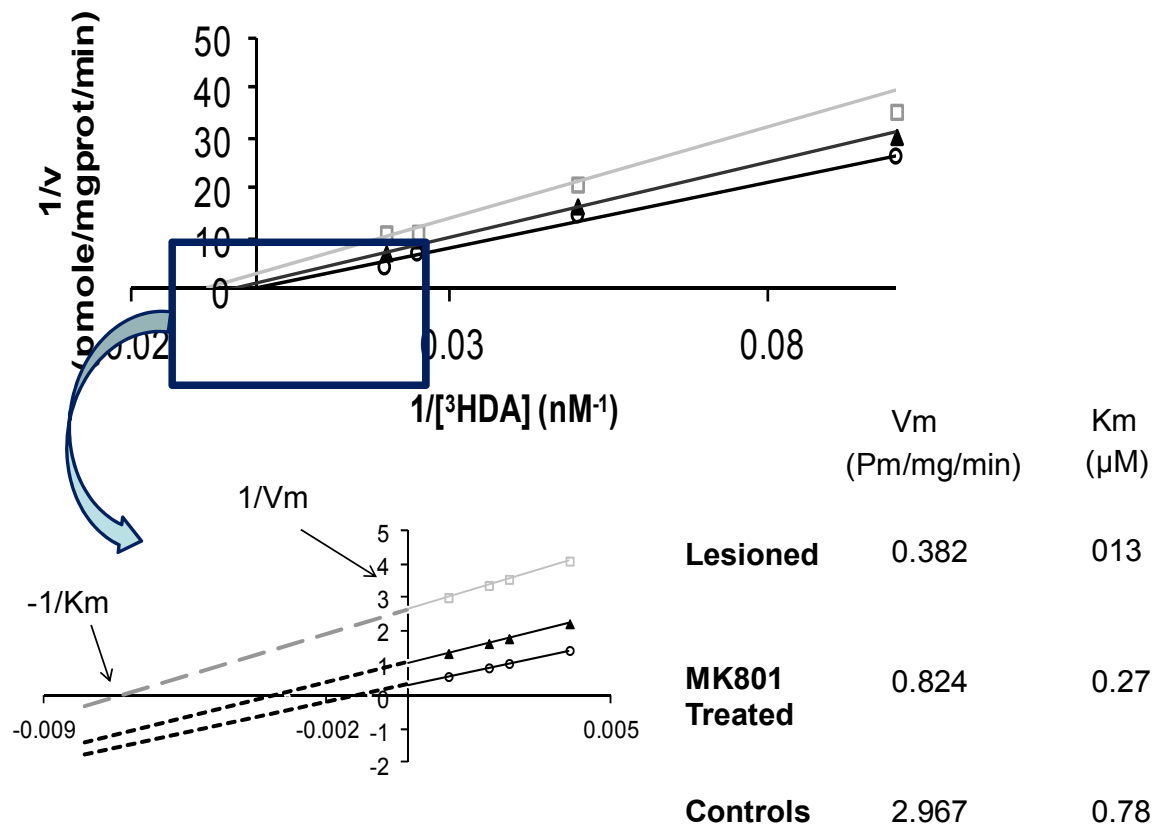

Fig. 10. Lineweaver-Burk plot of $\left[{ }^{3} \mathrm{H}\right] \mathrm{DA}$ capture in striatal synaptosomes 
The apparent $K_{\mathrm{m}}$ and $V_{\max }$ of the $\left.{ }^{3} \mathrm{H}\right] \mathrm{DA}$ transport reaction were calculated by linear regression (Fig. 10). The slopes of the curves obtained for lesioned-only animals and lesioned plus MK801-treated animals were both significantly different from that of shamoperated animals $(\mathrm{P}<0.05)$. The values of $V_{\max }$ were $2.967,0.382$ and $0.824 \mathrm{pmole} / \mathrm{mg}$ $\mathrm{prot} / \mathrm{min}$ respectively for sham-operated, lesioned and lesioned + MK801-injected rats. The $K_{\mathrm{m}}$ values were $0.78,0.13$ and $0.27 \mu \mathrm{M}$ respectively.

\subsection{Nigrostriatal lesion reduces DA uptake but increases DA transport}

The reduction in the levels of tissue DA and DOPAC appeared soon after the first injection. The DOPAC/DA ratio, reflecting TH protein activity (Lavielle et al., 1978; Bannon \& Roth, 1983; Zetterström et al., 1988; Nissbrandt et al., 1989; Soares da Silva \& Garret, 1990), and the amount of $\mathrm{TH}$ protein in the tissue remained unchanged during the first 6 weeks. This reduction in intraterminal DA stores that is not associated with changes in DA synthesis is consistent with the observations that we report below of increased basal DA release during the very early phases of denervation (Dentresangle et al., 2001; Dzahini et al., 2010).

After six and eight injections, both the tissue DA and DOPAC continued to decrease and tissue levels of TH protein began to decline. In contrast, the DOPAC/DA ratio increased, confirming a delay in increased DA synthesis. This could be the result of decreased intraterminal DA. TH activity is under the control of cytoplasmic amine levels through an end-product regulatory process (Ames et al., 1978; Mann and Gordon, 1979; Zigmond et al., 1989; Fillenz, 1993). Therefore increased TH activity, which is often reported after partial lesion of the DA pathway (Zigmond et al., 1990) could be, at least in part, a consequence of reduced intraterminal DA pools. The simultaneous reduction in the amount of tissue TH protein may occur in one of two ways: (1) a reduction in the number of DA terminals, or (2) increased protein turnover associated with the increased catalytic activity (Vrana and Roskoski, 1983; Lavergne et al., 1994).

This set of results is consistent with the hypothesis that the preservation of extracellular DA after partial destruction of the nigro-striatal DA pathway is due to activation of basal DA release. However, as already mentioned, this is unlikely to be the result of electrical activation of DA neurons in the SNc. Thus, alterations in DA transport at the level of the DA terminals in the STR are more likely.

The amplitude of the denervation produced by eight injections of the toxin was evaluated initially. The amount of $\mathrm{TH}$ protein and the binding of transport sites are considered to be valid indices of DA pathway denervation (van Horne et al., 1992; Maloteau, 1998). In the present experiment, tissue $\mathrm{TH}$ protein levels were reduced to $63 \%$ of the levels found in controls, and the $B_{\max }$ of $\left[{ }^{3} \mathrm{H}\right] \mathrm{GBR} 12935$ was reduced to $60.4 \%$ of the value found in shamoperated animals. Thus, about $40 \%$ of DA terminals may have degenerated after eight injections of the toxin.

Given this $40 \%$ reduction in the number of binding sites in the synaptosomal preparation of lesioned rats, the kinetic parameters of the DA uptake process are apparently paradoxical. First, the global DA uptake was only reduced by $11 \%$ (insignificant decrease), and when adjusted according to the number of sites (reduced by $40 \%$ ), it was actually increased (146\% of controls). This observation suggests an increase in the efficiency of the transport process, compensating for the reduction in the population of DA terminals. Second, the $V_{\max }$, which 
is an index of transport capacity, was only $12 \%$ of the value in control rats. This observation shows that a large number of sites, still bound to [3H]GBR12935, had become unable to carry DA. Third, it can be concluded from the low $K_{m}$ value that the affinity of DA for the carrier protein had increased. These results strongly suggest that moderate DA denervation of the STR results in a reduction in the number of functional DA transporters able to carry DA, but an increase in their affinity, which is responsible in turn for an increased rate of transport. We will see below that a new way to see the structure of the DAT protein could underline this paradoxical data. Indeed DAT is no longer considered as only an uptake processor but rather as a dual actor of the DA transport regulating extracellular DA homeostasis.

\section{Presynaptic GLU - Induced activation of DA release in the STR after partial nigral lesion}

The behavioral and biochemical recovery, after partial unilateral lesion, of the dopaminergic nigrostriatal path has been reported in various species from rodents to primates (Hefti et al., 1985; McCallum et al., 2006; Boulet et al., 2008; Perez et al., 2008). This recovery is thought to result from normalization of the extracellular dopamine $\left(\mathrm{DA}_{e x t}\right)$ in the STR that was initially reduced by the lesion (Robinson and Whishaw, 1988; Castaneda et al., 1990; Zigmond et al., 1990; Emmi et al., 1996). However, it remains unclear whether this compensation results from overactive nigral neurons, as is proposed to occur after LevoDOPA treatment (Grace, 2008), from direct preterminal influences in the STR (Dentresangle et al., 2001), or from both. A role for GLU in this phenomenon has been proposed given that the GLU tone increases in various regions of the basal ganglia following SNc lesions, including in the STR (Calabresi et al., 1993; Cepeda et al., 2001; Tang et al., 2001), the SNc (Turski et al., 1991; Bezard et al., 1997) and the subthalamic nucleus (Benazzouz et al., 1993; Amalric et al., 1995; Phillips et al., 2006). This was confirmed by the fact that behavioral and biochemical recovery were inhibited by chronic treatment with GLU receptor $\left(G L U_{R}\right)$ antagonists including MK801 (see the preceding paragraph) and 3-[(R)-2-carboxypiperazin-4-yl]-prop-2-enyl-1-phosphonic acid (CPP) (Emmi et al., 1996). The nature of the mechanisms evoked by GLU remains unclear however, because compensatory mechanisms occur very early or following very partial lesions, at a stage at which the spontaneous activity of midbrain DA neurons was not found to be altered (Hollerman and Grace, 1990) and when the impulse/release ratio in the terminal region appeared unchanged (Dentresangle et al., 2001). To complicate the situation, it is now well known that GLU can enhance DA release independently from the spontaneous electrical activity of the midbrain DA neurons (Leviel et al., 1990; Keefe et al., 1992; Olivier et al., 1995, 1999).

\subsection{Experimental observations}

To understand the functional link between DA and GLU during the compensatory process a very partial and laterally located lesion of the SN was produced in rats using 6-OHDA. Three weeks after this lesion, it was possible to compare the metabolic consequences of a large denervation in the lateral part of the STR with those in a medial region spared by the denervation. Cartography of the tonic extracellular DA and DOPAC concentration was performed using in vivo voltammetry. In rats with similar lesions medial and lateral microdialysis approaches allowed us to measure the extracellular GLU concentration. The effect of GLU antagonists (amantadine, memantine and riluzol) on neurotransmission and their neuroprotective action on tonic DA enhancement were also tested. 


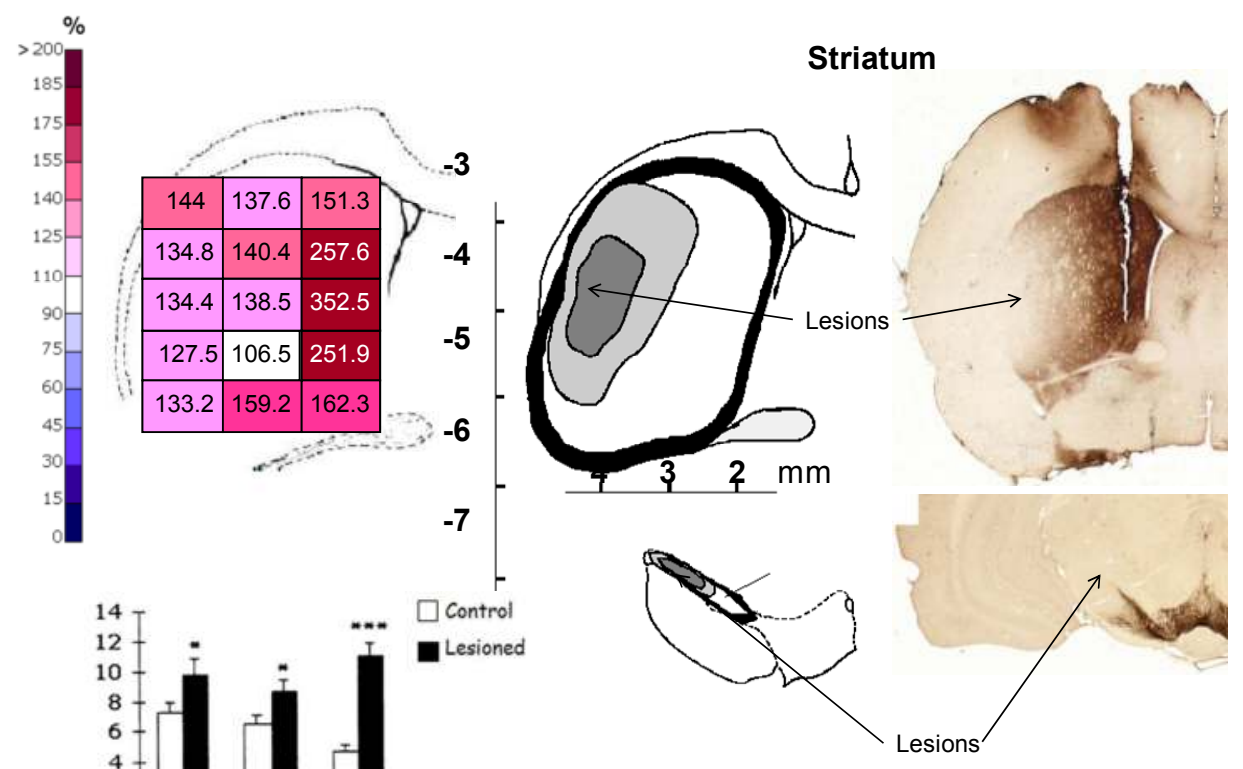

Subs. Nigra

Fig. 11. Lateral lesion of the SN and its consequences for striatal DA denervation and release

Cartography of the STR using voltammetry

The STR was stereotaxically explored in one coronal plane ( $8.2 \mathrm{~mm}$ anterior to the ear axe) to localize biochemical changes in vivo. Figure 11 shows the extracellular concentrations of DA expressed in $\mathrm{nM}$ and as the ratio (in \%) between values obtained in lesioned and control animals in each homologous striatal area for each subregion explored. In the lesioned animals, DA measured in the intact median region (lat. 2) showed a notable increase $(352 \%$, $\mathrm{p}<0.001)$ in comparison with control values. This effect was less pronounced in the intermediate and lateral striatal areas (lat. 3-4) but was nevertheless present. In the most completely DA-deafferented striatal regions, DA levels did not differ significantly from control values, being only slightly higher. In contrast, the extracellular level of DOPAC decreased enormously ( $26 \%$ of control values; $p<0.001$ ) in the lateral part of the STR in comparison with values detected in the homologous striatal region of the control group. In the medial region DOPAC concentrations remained poorly affected (Dzahini et al., 2010).

Effects of partial lesions of the $\mathrm{SN}$ and microdialysis results

Voltammetry furnishs excellent stereotaxic localization of biochemical alterations but the use of pargyline to detect DA could produce a bias in the measurements. To better quantify the changes observed with voltammetry, and to extend the measurements to amino acids, the medial spared region was implanted with a microdialysis probe, and superfusates were subjected to HPLC and two analyses, one for catecholamines and the other for amino acids. In sham-operated and untreated rats, the spontaneous extracellular concentrations of DA $(7.28 \pm 0.36 \mathrm{nM})$, DOPAC $(9.19 \pm 1.1 \mu \mathrm{M})$, HVA $(6.54 \pm 0.59 \mu \mathrm{M})$, GLU $(10.0 \pm 0.27 \mu \mathrm{M})$, GABA 
$(0.42 \pm 0.06 \mu \mathrm{M})$ and ASP $(0.47 \pm 0.05 \mu \mathrm{M})$ were in the range of previously reported values. Importantly, DA was in the nano molar range in the extracellular space whereas metabolites and amino acids were in the micro molar range. Three weeks following the lesion in the lateral part of the SN, an increase in DA was detected in the medial STR $(29.2 \pm 0.28 \mathrm{nM})$. Simultaneously an increase in GLU was observed $(24.4 \pm 0.75 \mu \mathrm{M})$. In contrast, the DA metabolites, DOPAC $(10.8 \pm 0.10 \mu \mathrm{M})$ and HVA $_{\text {ext }}(8.86 \pm 0.90 \mu \mathrm{M})$, remained unchanged. Likewise, GABA $(0.63 \pm 0.17 \mu \mathrm{M})$ and ASP $(0.47 \pm 0.05 \mu \mathrm{M})$ were not significantly altered.

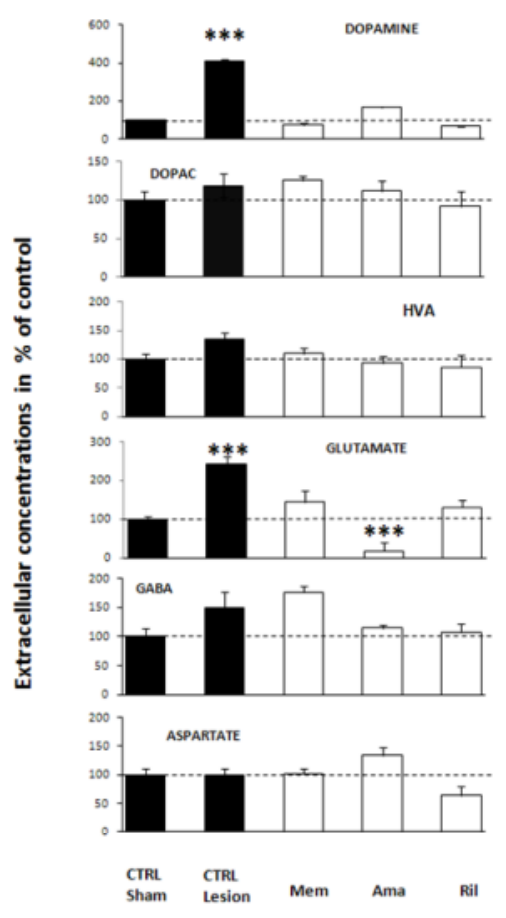

Fig. 12. Tissue DA and amino acid in the striatum 3 weeks following lesioning of the SN using 6-OHDA

Treatment of lesioned rats with GLU antagonists

Treatment with chronic memantine, amantadine or riluzol seemed to counteract the tonic increase in DA induced following the lesion that was observed via voltammetry and confirmed using microdialysis (Fig. 12). Only a moderate increase in DA persisted following chronic amantadine administration $(12.4 \pm 1.26 \mathrm{nM}$ versus $7.28 \pm 0.36 \mathrm{nM}$ in controls). The DA concentration remained at basal levels following treatment with memantine and riluzol (Fig. 12). Acute treatments with the same substances were less efficient at counteracting the increase in DA but the same trends were apparent $(15.1 \mathrm{nM}, 24.1 \mathrm{nM}$ and $24.4 \mathrm{nM}$ respectively for memantine, amantadine and riluzol versus $29.2 \mathrm{nM}$ in the controls, Dzahini et al., 2010). The GLU antagonists did not interact with the DA metabolites DOPAC and HVA. The results are presented in Fig. 12 as percentages of the values obtained in lesioned rats. 
The extracellular GLU concentration increased tonically after the lesion $(24.4 \pm 0.75 \mu \mathrm{M}$ versus $10.0+0.27 \mu \mathrm{M}$ in controls). This effect was counteracted by treatment with either chonic or acute memantine $(47.1 \pm 2.3 \mu \mathrm{M}$ and $27.1 \pm 1.53 \mu \mathrm{M}$ respectively). Chronic riluzol also counteracted the lesion-induced increase in GLU after chronic application $(21.8 \pm 0.68$ $\mu \mathrm{M})$ and acute riluzol drastically reduced GLU $(0.7 \pm 0.05 \mu \mathrm{M})$. GLU was also reduced after both chonic and acute amantadine treatment $(1.04 \pm 0.4 \mu \mathrm{M}$ and $0.74 \pm 0.26 \mu \mathrm{M}$ respectively). No alterations in GABA or ASP were detected in response to the treatment of lesioned rats with GLU antagonists. The results obtained after chronic treatments are presented in Fig. 12 as the percentage of values obtained in lesioned rats. The results obtained after acute treatments are presented elsewhere (Dzahini et al., 2010).

Substantially, the lesion produced a large increase in DA and GLU in the medial STR that was not accompanied by noticeable alterations in the two DA metabolites or the other two amino acids that were measured. The three treatments with GLU antagonists seemed to affect DA metabolism in the same way, counteracting the lesion-induced increase in DA. These treatments had differential effects on GLU.

Twenty-one days after the lesion, the denervated part of the STR (lateral) exhibited biochemical responses previously described after high levels of DA cell depopulation: a drastic reduction in DOPAC and an unmodified or slightly increased DA (Zigmond et al., 1984; Altar et al., 1987). In contrast, a large increase in DA (two- to three-fold) and a modest alteration in DOPAC was observed using voltammetry and confirmed using microdialysis in the spared part of the STR (medial). In this case, the levels of DA probably resulted from permanent (tonic) enhancement of the spontaneous release of DA. It has been shown that partial lesions leave the stimulation/release ratio unmodified (Dentresangle et al., 2001). A much larger lesion of the DA cell population seems to be required to alter the spontaneous pattern of discharge of nigral DA cells (Hollerman and Grace, 1990; Harden and Grace, 1995) or stimulation-induced DA release (Stachowiak et al., 1987). These observations strongly suggest that after lateral SN lesion, a global process activates tonic DA release by an indirect mechanism acting presynaptically in the STR.

It has been claimed that recovery of the DA in the STR after partial lesions of the SN could be related to alterations in GLU neurotransmission (Calabresi et al., 2000; Emmi et al., 1996; Kashani et al., 2007). However, the mechanism and the location of this alteration remain unknown. We found that 3 weeks after the lesion, GLU was clearly enhanced in the medial STR. When GLU neurotransmission was pharmacologically interrupted by specific GLU blockers (riluzol, memantine and amantadine), a reduction in extracellular GLU activation was observed, with a simultaneous reduction in the tonic DA increase induced by the nigral lesion.

Amantadine and memantine were proposed to have some neuroprotective effects after discovering the importance of NMDA receptor-mediated excitotoxicity as a factor underlying neurodegeneration in Parkinson's disease (Greenamyre and O'Brien, 1991). Indeed antagonists of NMDA receptors have been shown to inhibit neurodegeneration of the DA system induced by MPP+ and methamphetamine (Sonsalla et al., 1989; Turski et al., 1991). In our case, the effect of the two GLU antagonists was to counteract the increase in GLU and DA induced by the nigral lesion. Several studies have suggested that NMDAinduced DA release could be the main regulatory mechanism of extracellular DA (Bannon et al., 2001; Leviel, 2001; Mortensen and Amara, 2003), and our observations are consistent 
with the hypothesis of a NMDA-induced mechanism causing stable dopaminergic hypertony. The effects of riluzol strengthen this hypothesis. First proposed to inhibit GLU release (Mantz, 1992), its action has also been attributed to persistent blockade of the sodium current (Del Negro, 2005). In our hands, riluzol reduced the release of GLU in sham-operated animals and counteracted the lesion-induced GLU and DA as well (Dzahini et al., 2010).

\section{Conclusions: DA/GLU, a deleterious partnership?}

To summarize the present results and referenced data, the most original outcome is that DA release in the STR is not simply a readout of activity in DA neurons that provide a diffuse DA tone in the extracellular space. Rather, DA can be released by at least two different mechanisms with different kinetics, locations and regulatory processes. Based on the data reported here, a working hypothesis can be proposed: that a weak reduction in the DA cell population in the SNc leads to metabolic alterations in the STR that result in further death of DA terminals in this region. The development of this process could follow three major steps (Fig. 13): 1) the activation of diencephalic structures, thalamic or sub-thalamic nuclei that

\section{Dopamine and Glutamate Hypertony in Parkinson' Disease}

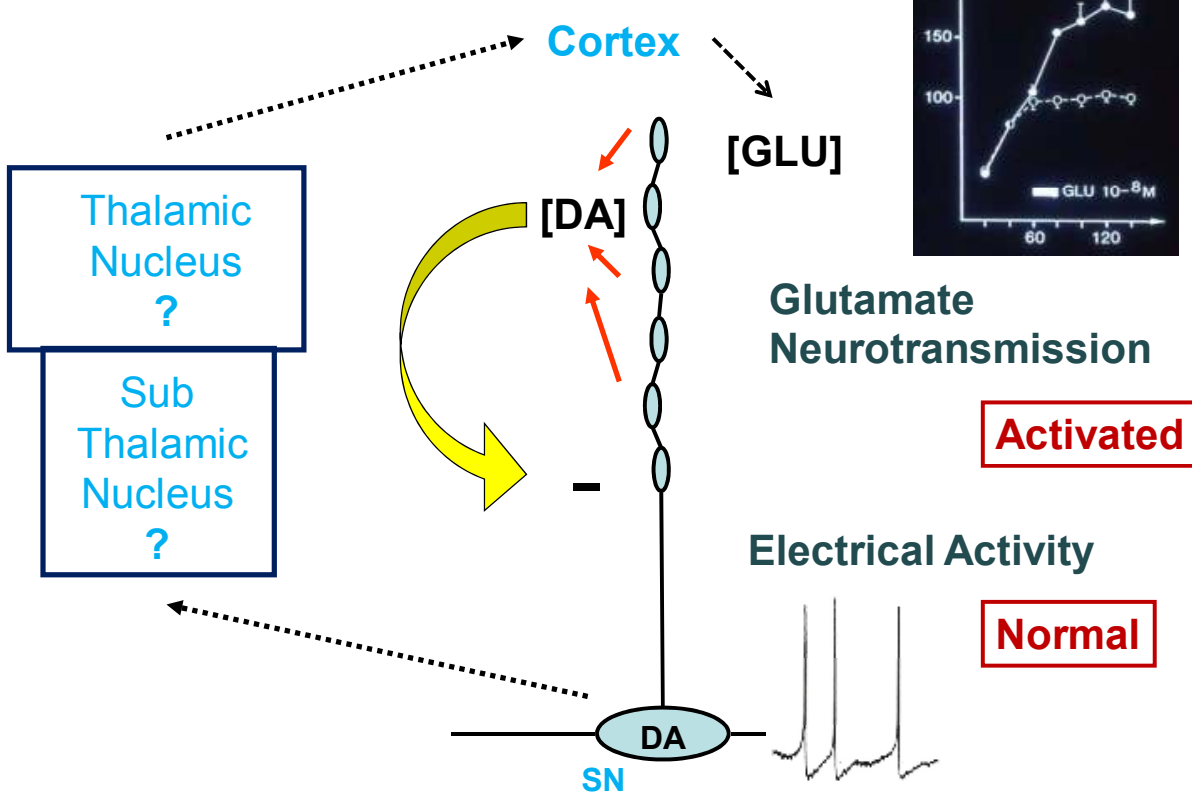

Fig. 13. A working hypothesis of the mechanism involved in the presymptomatic phase of PD

project toward cortical regions; 2) in turn, a tonic increase in some of the corticostriatal pathways that we know to be responsible for different controls of the striatal GABA neurons 
and DA terminals; 3) indirect activation through GLU afferents to DA terminals of tonic DA release, which initially constitutes autotherapy allowing the behavioral compensation observed in Parkinson's disease. However the toxic effect of DA on the DA terminal (production of $\mathrm{H}_{2} \mathrm{O}_{2}$ when present in excess) could constitute a secondary pathological agent, maintaining the degenerative process. Each of the three steps mentioned here require further elucidation and demonstration, but a large set of data in each case is consistent with this hypothesis.

DA homeostasis constitutes one of the functions of the DAT via DAT-RT. This is under the control of many regulatory processes including tonic GLU neurotransmission. Experiments regarding the consequences of partial lesions seem to indicate a role for this GLU-dependent regulation in the tonic DA overflow and in maintaining a permanent excess of extracellular DA. It remains to be determined how local GLU can induce the presynaptic and tonic activation of DA release. This could be achieved directly through GLU receptors located on DA terminals or indirectly through heterologous neurotransmission systems such as GABA or $\mathrm{ACH}$.

\section{Technical procedures}

\subsection{Animals}

Male Wistar rats (Iffa-Credo France) weighing $250 \mathrm{~g}$ were used in the studies reported here. They were maintained and sacrificed in accordance with the European Communities Council Directive (86/609/EEC). The animals were anesthetized with $1.5 \%$ isoflurane in pure oxygen in air or were injected with chloral hydrate $(400 \mathrm{mg} / \mathrm{kg})$ and spontaneously inspired (Leviel et al., 1989; Olivier et al., 1995). When necessary they were placed in a stereotaxic device. For the short interventions (less than 1 hour), a mixture of ketamine/rompun was used $(150 / 10 \mathrm{mg} / \mathrm{Kg})$. Rectal temperature was maintained at $38^{\circ} \mathrm{C}$. Cardiac and respiratory rhythms were continuously monitored.

\subsection{Lesions of the lateral SN}

The lateral part of the SN was unilaterally injected with a solution of 6-OHDA (3 $\mu$ g free base in $1 \mu \mathrm{l}$ isotonic saline containing $0.2 \%$ ascorbic acid, $\mathrm{pH} 4$ ). The stereotaxic coordinates were, in mm: Ant.: 3.5, Lat.: 2.5 and Ht.: 3.4. The horizontal plane passed through the interaural axis and incisor bar. Unlesioned rats were only submitted to nigral injection of the vehicle (Dentresangle et al., 2001; Dzahini et al., 2010).

\subsection{Surgery and procedures for recurrent ventricular injections}

Animals were anesthetized with ketamine (150 mg/Kg; Panpharma), maintained in a stereotaxic device and implanted with a cannula $(0.71 \mathrm{~mm}$ o.d. with a removable mandrel) in the anterior part of the left lateral ventricle. The head of the cannula was sealed with acrylic cement, embedding screws set in the cranial bone. The stereotaxic coordinates were the following (in mm): AP: 0.48; LM: 1; H: 6 from the bregma (following Paxinos and Watson, 1986). Rats were allowed to recover for 2 weeks. In order to inject 6-OHDA (30 min after administering $25 \mathrm{mg} / \mathrm{kg}$ imipramine i.p. to protect noradrenergic neurons), the mandrel of the cannula was removed and replaced by an injector connected, through a thin 
catheter, to a microsyringe. Weekly injections of $10 \mu \mathrm{l}$ of a solution $(0.1 \%$ ascorbic acid in $0.9 \% \mathrm{NaCl}$ ) with or without $35 \mu \mathrm{g}$ of 6 -OHDA were given to awake and freely moving animals. Four groups of 12 animals received 2, 4, 6 or 8 weekly injections of the toxin $(n=6)$ or the toxin vehicle only $(n=6)$. A fifth group $(n=6)$ of rats received 8 weekly injections of the toxin and a daily injection of $2 \mathrm{mg} / \mathrm{kg}$ MK801 (i.p.).

\subsection{Medial Forebrain Bundle (MFB) stimulation}

A bipolar electrode was implanted in the medial forebrain bundle (MFB) containing the DA ascending fibers (coordinates: A:5; L:1.3; Ht:2). Every 4 minutes, the MFB was stimulated for 20 seconds by 20 bursts (one per second) of 25 positive square pulses, each lasting $0.5 \mathrm{~ms}$, with a $2 \mathrm{~ms}$ interpulse interval ( $40 \mathrm{~Hz}$ theoretical frequency). Each burst was triggered 300 ms after the measurement of DPA (Dentresangle et al., 2001; Dzahini et al., 2010).

\subsection{Voltammetric investigations}

Difference Normal Pulse Voltammetry (DNPV) and Differential Pulse Amperometry (DPA) were performed using treated carbon fiber electrodes produced as described previously (Olivier et al., 1995; Dentresangle et al., 2001). Their active part was the surface of one pyrolytic carbon fiber (SOFICAR, France), $250 \mu \mathrm{m}$ long and $8 \mu \mathrm{m}$ in diameter. A stainless steel tweezer fixed on the interaural bar was used as an auxilliary electrode and the $\mathrm{Ag} / \mathrm{AgCl}$ reference electrode was a silver wire coated with $\mathrm{AgCl}$. This was maintained in contact with the skull by means of a sponge moistened with Phosphate Buffer Saline (PBS) solution (PBS, pH 7.4). The three electrodes were connected to a pulse voltammetric system (Biopulse, SOLEA Tacussel, France). Carbon-fiber electrodes were electrochemically treated as previously described (Gonon et al., 1984). To calibrate the electrodes, voltammograms were recorded in vitro in a standard solution of DOPAC or DA and ascorbic acid in PBS. The values of the oxidation potentials and the amplitude of the peaks were stabilized after 4-5 successive scans (10 to $15 \mathrm{~min}$ ). Their values were $60 \mathrm{mV}$ for ascorbic acid, $60 \mathrm{mV}$ for DOPAC and $90 \mathrm{mV}$ for DA. It had previously been verified that the amplitude of the oxidation peak for these substances is linearly correlated with their concentrations. The oxidation potentials for DA and DOPAC were however too close to be properly differentiated in vivo and DA was three orders of magnitude lower than DOPAC. Thus, for adequate detection of DA, DOPAC formation was inhibited by pretreatment with pargyline (75 mg/kg, i.p.), an inhibitor of monoamine oxidase.

\subsection{Superfusion procedures (microdialysis \& push-pull cannula)}

Animals were submitted to superfusion of the striatum to analyze extracellular DA, DOPA, HVA, GLU, GABA and ASP (Dzahini et al., 2011). They were implanted with a dialysate probe $(250 \mu \mathrm{m}$ in diameter and $4 \mathrm{~mm}$ length, cut off 6000 dalton, CMA, Sweden) in the anterior part of the caudate nucleus (Ant.: $8.4 \mathrm{~mm}$; Lat.: $2.5 \mathrm{~mm}$; H.: $6 \mathrm{~mm}$, same stereotaxic references). The cannula was supplied $(1 \mu \mathrm{l} / \mathrm{min}$ ) with an artificial CSF (in mM, $145 \mathrm{NaCl}$, 2.7 KCl, $1.0 \mathrm{MgCl}_{2}, 1.2 \mathrm{CaCl}_{2}, 0.45 \mathrm{NaH}_{2} \mathrm{PO}_{4}, 2.3 \mathrm{Na}_{2} \mathrm{HPO}_{4}$, adjusted to $\mathrm{pH}$ 7.4).

Push-pull cannulae were used in an experiment devoted to measuring the radioactive form of DA and DOPAC (Leviel et al., 1989, 1990, 1991). The cannulae (1.0 mm outer diameter) were supplied (flow rate: $12.5 \mu \mathrm{l} / \mathrm{min}$ ) with an artificial cerebrospinal fluid (CSF) adjusted to pH 7.4 with an $\mathrm{O}_{2}-\mathrm{CO}_{2}(95: 5 \mathrm{v} / \mathrm{v})$ mixture. 3,5-[3 $\left.\mathrm{H}\right] \mathrm{TYR}(50 \mathrm{Ci} / \mathrm{mmole}$, Dositek, France) was 
purified by high performance liquid chromatography (HPLC) on a $\mathrm{C}_{18}$ Microbondapak column (Millipore-Waters, France) using $\mathrm{H}_{3} \mathrm{PO}_{4}(1 \mathrm{mmol} / \mathrm{l}, \mathrm{pH} 3)$ as a mobile phase. [3H]TYR was added to artificial CSF $(80 \mu \mathrm{Ci} / \mathrm{ml}) 1$ hour after implantation and superfusates were collected thereafter as successive 20 minute fractions.

\subsection{Biochemical analysis}

Dialysates collected for measuring catecholamines were protected with $5 \mu \mathrm{l}$ perchloric acid $(0.05 \mathrm{M})$ and immediately underwent HPLC analysis. Dialysates collected for amino-acid analysis were maintained at $-80^{\circ} \mathrm{C}$ and kept frozen until analysis.

The catecholamines DA, DOPAC and HVA were measured in the collected fractions by electrochemical detection with the potential of the working electrode maintained at $0.7 \mathrm{~V}$ (Antec-Decade) after HPLC separation (column $\mathrm{C}_{18}$ Brownlee RP18, $5 \mu \mathrm{m}, 2.1 \times 220 \mathrm{~mm}$, maintained at $32{ }^{\circ} \mathrm{C}$; Mobile phase: $50 \mathrm{mM} \mathrm{KH}_{2} \mathrm{PO}_{4}, 0.1 \mathrm{mM}$ EDTA-Na, $0.28 \mathrm{mM}$ sodium octyl sulfate, $6 \%$ methanol, adjusted to $\mathrm{pH} 4.5$; flow rate $0.25 \mathrm{ml} / \mathrm{min})$. Catecholamine peaks were identified based on their retention times (Olivier et al., 1995; Dzahini et al., 2010). Extracellular catecholamine concentrations were estimated by evaluating the peak areas of each substance and their respective external standard (analytical software AZUR, Datalys France). The running time for each determination was $25 \mathrm{~min}$. When superfusion was conducted with 3,5-[3H]TYR added to the CSF, the radioactivity corresponding to each HPLC peak was counted using a continuous flow scintillation detector (PackardRadiomatic, Flo-One B A250)( Leviel et al., 1989, 1990, 1991).

The concentrations of the amino acids GLU, GABA and ASP in the dialysates were determined after HPLC, via laser-induced fluorescence detection (Dzahini et al., 2010). Briefly, $2 \mu \mathrm{l}$ of sample or standard was derivatized with naphthalene-2,3-dicarboxaldehyde. The resulting mixture was automatically loaded onto a Symmetry Shield- $\mathrm{C}_{18}$ reverse-phase column (100_2.1 mm, 3.5 _m particle size; Waters, Milford, MA), using a refrigerated Triathlon auto injector (Polymer Laboratories, Marseille, France). The mobile phase consisted of $0.04 \mathrm{M} \mathrm{NaH}_{2} \mathrm{PO}_{4}, \mathrm{pH}$, in a 3-50\% acetonitrile gradient. The flow rate was 0.35 $\mathrm{ml} / \mathrm{min}$, maintained using two Shimadzu (Kyoto, Japan) LC 10AT pumps. Amino acid peaks were identified based on their retention time. Extracellular amino acid concentrations were estimated by evaluating the peak areas of each amino acid and their respective external standard (analytical software class LC10; Shimadzu). The running time for each determination was $12 \mathrm{~min}$.

\subsection{DA and DOPAC tissue concentration}

At the end of each experiment, to verify the location of the cannula, the animals were intracardially perfused with a $4 \%$ formaldehyde solution, after which the brain was removed, sliced $(50 \mu \mathrm{m})$ and stained with cresyl violet.

Protein weights were measured using the micro BCA Protein Assay (Pierce, Biorad).

The homogenate $(20 \mu \mathrm{l})$ was mixed with $20 \mu \mathrm{l}$ of $0.3 \mathrm{~N}$ perchloric acid containing $0.8 \mathrm{mM}$ EDTA, added to an internal standard (3,4-dihydroxybenzylamine) and centrifuged $(10,000$ $\mathrm{g}, 10 \mathrm{~min})$. The supernatant of each sample $(10 \mu \mathrm{l})$ was injected into a C18 reverse-phase microcolumn (Spheri5, RP-18, $220 \times 2.1 \mathrm{~mm}$, Browlee labs). The mobile phase consisted of 40 $\mathrm{mM} \mathrm{KH} 2 \mathrm{PO}_{4}(\mathrm{pH} 4.5), 0.26 \mathrm{mM}$ octane sulfonic-acid, $15 \mathrm{mg} / 1$ EDTA and 11\% methanol 
(vol/vol), and the flow rate was $0.20 \mathrm{ml} / \mathrm{min}$. The liquid chromatography system (TSP) was coupled to an electrochemical detector (Millipore) with a working electrode set at $0.8 \mathrm{~V}$. The concentrations of DA and its metabolites in $\mathrm{CP}$ were calculated for each sample (in $\mathrm{ng} / \mathrm{mg}$ prot). The results were normalized by expressing the changes in DA and DOPAC levels as percentages of the values obtained in control animals (Dentresangle et al., 2001).

\subsection{Preparation of synaptosomes}

The method for synaptosomal preparation and measurement of [ $\left.{ }^{3} \mathrm{H}\right] \mathrm{DA}$ uptake was modified from Masserano et al. (1994). Rat brains were rapidly removed and chopped into 1.6-mm-thick slices, in the sagittal plane corresponding to the anterior commissura. The median part of the $\mathrm{CP}$, ipsilateral to the injection site, was pooled for all rats of each group and homogenized in $25 \mathrm{ml}$ cold $0.32 \mathrm{M}$ sucrose (10 up and down strokes, at $850 \mathrm{rpm}$, in a glass-teflon homogenizer). The homogenate was centrifuged at $800 \mathrm{~g}$ for $10 \mathrm{~min}$ at $4{ }^{\circ} \mathrm{C}$ and the pellet was discarded. The supernatant (S1) was kept on ice until it was resuspended for the $\left[{ }^{3} \mathrm{H}\right] \mathrm{DA}$ uptake or $\left[{ }^{3} \mathrm{H}\right] \mathrm{GBR} 12935$ binding protocols.

[ $\left.{ }^{3} \mathrm{H}\right] \mathrm{DA}$ uptake: The supernatant $(\mathrm{S} 1,15 \mathrm{ml})$ was centrifuged $\left(20,000 \times \mathrm{g}\right.$ for $10 \mathrm{~min}$ at $\left.4{ }^{\circ} \mathrm{C}\right)$, and the resulting pellet (P2) was resuspended in $20 \mathrm{ml}$ of ice-cold incubation buffer (in $\mathrm{mM}$ ): $\mathrm{NaCl}, 125 ; \mathrm{K}_{2} \mathrm{HPO}_{4}, 1.5 ; \mathrm{MgSO}_{4}, 1.5 ; \mathrm{CaCl}_{2}, 1.25 ;$-glucose, 10; HEPES, 25; ascorbic acid, 0.1; pargyline, 1 and EDTA, 0.1, pH 7.4. The buffer was oxygenated with $100 \% \mathrm{O}_{2}$ for $10 \mathrm{~min}$ before use. The assays were performed in triplicate with $400 \mu \mathrm{l}$ of pellet resuspended in $1 \mathrm{ml}$ of incubation buffer. After preincubation of $3 \mathrm{~min}$ at $37^{\circ} \mathrm{C}$, the assays were initiated by adding $10 \mu \mathrm{l}$ of increasing concentrations of [ $\left.{ }^{3} \mathrm{H}\right] \mathrm{DA}(10,20,40,50,100,200,400 \mathrm{nM})$ for 7 $\min$ at $37^{\circ} \mathrm{C}$. Nonspecific values were determined in the presence of Mazindol $(1 \mu \mathrm{M})$ for 7 min at $4{ }^{\circ} \mathrm{C}$. Assays were terminated by immediate filtration using Whatman GF/B filters soaked in $0.32 \mathrm{M}$ ice-cold sucrose containing $0.05 \%$ polyethylenimine. Filters were washed three times with $3 \mathrm{ml}$ of $0.32 \mathrm{M}$ ice-cold sucrose and radioactivity was measured using a Packard TRI-CARB 2100 TR. The apparent $K_{\mathrm{m}}$ and $V_{\max }$ of DA uptake were calculated by linear regression of the reciprocal plot $(1 / v$ vs. $1 / S)$. The protein content in the resuspended pellet P2 was measured using the micro BCA kit (Pierce, Biorad).

\section{$7.10\left[{ }^{3} \mathrm{H}\right] \mathrm{GBR} 12935$ binding}

The $\left[{ }^{3} \mathrm{H}\right] \mathrm{GBR} 12935$ binding protocol was modified from Berger et al. (1985). The supernatant $(\mathrm{S} 1,10 \mathrm{ml})$ was centrifuged $\left(20,000 \mathrm{~g}\right.$ for $10 \mathrm{~min}$ at $\left.4{ }^{\circ} \mathrm{C}\right)$, and the resulting pellet (P2) was resuspended in $13 \mathrm{ml}$ of $50 \mathrm{mM}$ ice-cold Tris- $\mathrm{HCl}$ buffer, $\mathrm{pH} 7.7$, containing $120 \mathrm{mM} \mathrm{NaCl}$. Assays were performed in triplicate with $500 \mu \mathrm{l}$ of pellet suspension and $50 \mathrm{mM}$ Tris- $\mathrm{HCl}$ buffer, $\mathrm{pH} 7.7$, containing $120 \mathrm{mM} \mathrm{NaCl}$ and $0.01 \%$ of Bovine Serum Albumin in a final volume of $2 \mathrm{ml}$. Incubation was initiated by the addition of $100 \mu \mathrm{l}$ of [ $\left.{ }^{3} \mathrm{H}\right] \mathrm{GBR} 12935(5 \mu \mathrm{M})$ for $45 \mathrm{~min}$ at $25^{\circ} \mathrm{C}$. Non-specific binding was determined in the presence of $1 \mu \mathrm{M}$ Mazindol. Filters were washed three times with $4 \mathrm{ml}$ ice-cold Tris- $\mathrm{HCl} 50 \mathrm{mM}$ buffer $\mathrm{pH} 7.7$ and radioactivity was counted using a Packard TRI-CARB 2100 TR. The protein content in the resuspended pellet P2 was measured using the micro BCA kit (Pierce, Biorad).

\subsection{Determination of TH protein content}

$\mathrm{TH}$ protein content was measured using a semi quantitative immunoblotting technique as previously described by Garcia et al. (1994). Briefly, after centrifugation of the homogenate 
$(10,000 \mathrm{~g}, 30 \mathrm{~min}), 1.5 \mu \mathrm{l}$ of supernatant was placed onto a nitrocellulose membrane (Bio-rad 162-147, $0.2 \mu \mathrm{m})$. Non-specific binding sites were saturated with $50 \mathrm{mM}$ Tris buffer containing $2 \%$ bovine serum albumin. The protein was revealed using, in succession, a mouse monoclonal antibody to $\mathrm{TH}(10 \mathrm{ng} / \mathrm{ml}$; Boehringer Mannheim), a 125I-labeled protein A (S.A: 1.11x 10-9 Bq/mg, $1850 \mathrm{~Bq} / \mathrm{ml}$, Amersham) and 3H-hyperfilms (Amersham). The radioimmunochemical labeling was calibrated using a scale of standard $\mathrm{TH}$ protein (extracted from adult rat adrenals and diluted in homogenates of cerebellum). One U of TH (UTH) is defined as the mean TH protein content of $10 \mu \mathrm{g}$ (wet weight) of adult rat adrenal gland. Optical density measurements were converted into UTH/mg tissue by reference to the standards. Each reading provided the surface area $\left(\mathrm{mm}^{2}\right)$ of the dot and the TH tissue concentration (UTH/mg tissue). Using the surface area and the TH tissue concentration, the amount of TH (UTH) in the region of interest was calculated and normalized by expressing the amount of $\mathrm{TH}$ as a percentage of values in the control rats.

\subsection{Immunoprecipitation of TH enzyme}

Rats were perfused transcardially with $\mathrm{NaCl} 9 \%$ and PFA $4 \%$. The brain was then removed and stored in PBS buffer containing $0.1 \%$ sodium azide $\mathrm{pH} 7.4$ (PBSA). To evaluate the extent of the lesion in the $\mathrm{SN}$ and the extent of CPc denervation, $\mathrm{TH}$ immuno precipitation was performed on coronally sectioned slices (40-50 $\mu \mathrm{m}$ thickness). Brains were cut on a cryostat (HM440E, Microm); free-floating slices were collected and stored in PBSA. Sections were incubated in $3 \% \mathrm{H}_{2} \mathrm{O}_{2}$ in PBS to block endogenous peroxidase activity and were then incubated overnight with the primary rabbit anti-TH antibody (Chemicon, Temecula, CA; $1 / 2500$ ) in $10 \%$ normal swine serum, TBS, pH 7.4, containing $2 \%$ NGS and $0.2 \%$ Triton X-100 for $24 \mathrm{~h}$ at $4{ }^{\circ} \mathrm{C}$ on a platform shaker. After rinsing in PBS $0.1 \%$ plus triton $\mathrm{X} 100$, sections were incubated with biotinylated swine anti-rabbit secondary antibody for $30 \mathrm{~min}$ at room temperature. This was followed by incubation with Strept-ABC-HRP complex (Dako, Glostrup, Denmark). TH immunoreactive neurons were visualized using 3.3diaminobenzidine (DAB) in $\mathrm{N}^{2+} 0.5 \%$ and $\mathrm{H}_{2} \mathrm{O}_{2}$. To test the specificity of the staining, control sections were processed in an identical manner but with omission of the primary or secondary antibody. All sections were then washed for $10 \mathrm{~min}$ in PBS, mounted on slides, dried, dehydrated in increasing grades of ethanol, cleared in toluene, and mounted with DPX and cover slipped. These sections were scanned and analyzed immediately using Imagemaster Labscan V-3.00 (Pharmacia Biotech, Dzahini et al., 2010).

\section{Acknowledgment}

The work described here was supported by the Institut National de la Santé et de la Recherché Médicale, le Centre National de la Recherche Scientifique et Rhone Alpes Région.

\section{References}

Agnati, L. F.;Fuxe, K.;Zoli, M.;Ozini, I.;Toffano, G. \& Ferraguti, F. (1986).A correlation analysis of the regional distribution of central enkephalin and beta-endorphin immunoreactive terminals and of opiate receptors in adult and old male rats. Evidence for the existence of two main types of communication in the central nervous system: the volume transmission and the wiring transmission. Acta Physiol Scand, Vol.128, No.2, (Oct 1986), pp.(201-207), ISSN 0001-6772 
Albert, K. A.;Helmer-Matyjek, E.;Nairn, A. C.;Muller, T. H.;Haycock, J. W.;Greene, L. A.;Goldstein, M. \& Greengard, P. (1984).Calcium/phospholipid-dependent protein kinase (protein kinase C) phosphorylates and activates tyrosine hydroxylase. Proc Natl Acad Sci U S A, Vol.81, No.24, (Dec 1984), pp.(7713-7717), ISSN 0027-8424

Altar, C. A. \& Marien, M. R. (1989).Preservation of dopamine release in the denervated striatum. Neurosci Lett, Vol.96, No.3, (Jan 30 1989), pp.(329-334), ISSN 0304-3940

Altar, C. A.;Marien, M. R. \& Marshall, J. F. (1987).Time course of adaptations in dopamine biosynthesis, metabolism, and release following nigrostriatal lesions: implications for behavioral recovery from brain injury. J Neurochem, Vol.48, No.2, (Feb 1987), pp.(390-399), ISSN 0022-3042

Amalric, M.;Baunez, C. \& Nieoullon, A. (1995).Does the blockade of excitatory amino acid transmission in the basal ganglia simply reverse reaction time deficits induced by dopamine inactivation? Behav Pharmacol, Vol.6, No.5 And 6, (Aug 1995), pp.(508519), ISSN 0955-8810

Amejdki-Chab, N.;Benmansour, S.;Costentin, J. \& Bonnet, J. J. (1992).Effects of several cations on the neuronal uptake of dopamine and the specific binding of $[3 \mathrm{H}] \mathrm{GBR}$ 12783: attempts to characterize the $\mathrm{Na}+$ dependence of the neuronal transport of dopamine. J Neurochem, Vol.59, No.5, (Nov 1992), pp.(1795-1804), ISSN 0022-3042

Ames, M. M.;Lerner, P. \& Lovenberg, W. (1978).Tyrosine hydroxylase. Activation by protein phosphorylation and end product inhibition. J Biol Chem, Vol.253, No.1, (Jan 10 1978), pp.(27-31), ISSN 0021-9258

Arluison, M.;Agid, Y. \& Javoy, F. (1978).Dopaminergic nerve endings in the neostriatum of the rat--2. Radioautographic study following local micro-injections of tritiated dopamine. Neuroscience, Vol.3, No.8, 1978), pp.(675-683), ISSN 0306-4522

Augustine, G. J.;Charlton, M. P. \& Smith, S. J. (1987).Calcium action in synaptic transmitter release. Anпu Rev Neurosci, Vol.10, 1987), pp.(633-693), ISSN 0147-006X

Bannon, M. J.;Michelhaugh, S. K.;Wang, J. \& Sacchetti, P. (2001).The human dopamine transporter gene: gene organization, transcriptional regulation, and potential involvement in neuropsychiatric disorders. Eur Neuropsychopharmacol, Vol.11, No.6, (Dec 2001), pp.(449-455), ISSN 0924-977X

Benazzouz, A.;Gross, C.;Feger, J.;Boraud, T. \& Bioulac, B. (1993).Reversal of rigidity and improvement in motor performance by subthalamic high-frequency stimulation in MPTP-treated monkeys. Eur.J Neurosci., Vol.5, No.4, 1993), pp.(389), ISSN

Berger, T. W.;Kaul, S.;Stricker, E. M. \& Zigmond, M. J. (1985).Hyperinnervation of the striatum by dorsal raphe afferents after dopamine-depleting brain lesions in neonatal rats. Brain Res, Vol.336, No.2, (Jun 17 1985), pp.(354-358), ISSN 0006-8993

Blanchard, V.;Raisman-Vozari, R.;Vyas, S.;Michel, P. P.;Javoy-Agid, F.;Uhl, G. \& Agid, Y. (1994).Differential expression of tyrosine hydroxylase and membrane dopamine transporter genes in subpopulations of dopaminergic neurons of the rat mesencephalon. Brain Res Mol Brain Res, Vol.22, No.1-4, (Mar 1994), pp.(29-38), ISSN 0169-328X

Bogdanski, D. F. \& Brodie, B. B. (1969).The effects of inorganic ions on the storage and uptake of H3-norepinephrine by rat heart slices. J Pharmacol Exp Ther, Vol.165, No.2, (Feb 1969), pp.(181-189), ISSN 0022-3565 
Borland, L. M. \& Michael, A. C. (2004).Voltammetric study of the control of striatal dopamine release by glutamate. J Neurochem, Vol.91, No.1, (Oct 2004), pp.(220-229), ISSN 0022-3042

Boulet, S.;Mounayar, S.;Poupard, A.;Bertrand, A.;Jan, C.;Pessiglione, M.;Hirsch, E. C.;Feuerstein, C.;Francois, C.;Feger, J.;Savasta, M. \& Tremblay, L. (2008).Behavioral recovery in MPTP-treated monkeys: neurochemical mechanisms studied by intrastriatal microdialysis. J Neurosci, Vol.28, No.38, (Sep 17 2008), pp.(9575-9584), ISSN 1529-2401

Butcher, S. P.;Fairbrother, I. S.;Kelly, J. S. \& Arbuthnott, G. W. (1988).Amphetamine-induced dopamine release in the rat striatum: an in vivo microdialysis study. J Neurochem, Vol.50, No.2, (Feb 1988), pp.(346-355), ISSN 0022-3042

Calabresi, P.;Mercuri, N. B.;Sancesario, G. \& Bernardi, G. (1993).Electrophysiology of dopamine-denervated striatal neurons. Implications for Parkinson's disease. Brain, Vol.116 ( Pt 2), (Apr 1993), pp.(433-452), ISSN 0006-8950

Calabresi, P.;Picconi, B.;Saulle, E.;Centonze, D.;Hainsworth, A. H. \& Bernardi, G. (2000).Is pharmacological neuroprotection dependent on reduced glutamate release? Stroke, Vol.31, No.3, (Mar 2000), pp.(766-772; discussion 773), ISSN 0039-2499

Carter, C. J.;L'Heureux, R. \& Scatton, B. (1988).Differential control by N-methyl-D-aspartate and kainate of striatal dopamine release in vivo: a trans-striatal dialysis study. $J$ Neurochem, Vol.51, No.2, (Aug 1988), pp.(462-468), ISSN 0022-3042

Castaneda, E.;Whishaw, I. Q. \& Robinson, T. E. (1990).Changes in striatal dopamine neurotransmission assessed with microdialysis following recovery from a bilateral 6-OHDA lesion: variation as a function of lesion size. J Neurosci, Vol.10, No.6, (Jun 1990), pp.(1847-1854), ISSN 0270-6474

Castro, S. L.;Sved, A. F. \& Zigmond, M. J. (1996).Increased neostriatal tyrosine hydroxylation during stress: role of extracellular dopamine and excitatory amino acids. J Neurochem, Vol.66, No.2, (Feb 1996), pp.(824-833), ISSN 0022-3042

Cepeda, C.;Hurst, R. S.;Altemus, K. L.;Flores-Hernandez, J.;Calvert, C. R.;Jokel, E. S.;Grandy, D. K.;Low, M. J.;Rubinstein, M.;Ariano, M. A. \& Levine, M. S. (2001).Facilitated glutamatergic transmission in the striatum of D2 dopamine receptor-deficient mice. J Neurophysiol, Vol.85, No.2, (Feb 2001), pp.(659-670), ISSN 0022-3077

Cervinski, M. A.;Foster, J. D. \& Vaughan, R. A. (2005).Psychoactive substrates stimulate dopamine transporter phosphorylation and down-regulation by cocaine-sensitive and protein kinase C-dependent mechanisms. J Biol Chem, Vol.280, No.49, (Dec 9 2005), pp.(40442-40449), ISSN 0021-9258

Cheramy, A.;Leviel, V. \& Glowinski, J. (1981).Dendritic release of dopamine in the substantia nigra. Nature, Vol.289, No.5798, (Feb 12 1981), pp.(537-542), ISSN 00280836

Cheramy, A.;Romo, R.;Godeheu, G.;Baruch, P. \& Glowinski, J. (1986).In vivo presynaptic control of dopamine release in the cat caudate nucleus--II. Facilitatory or inhibitory influence of L-glutamate. Neuroscience, Vol.19, No.4, (Dec 1986), pp.(1081-1090), ISSN

Chubb, I. W.;De Potter, W. P. \& De Schaepdryver, A. F. (1972).Tyramine does not release noradrenaline from splenic nerve by exocytosis. Naunyn Schmiedebergs Arch Pharmacol, Vol.274, No.3, 1972), pp.(281-286), ISSN 0028-1298 
Ciliax, B. J.;Drash, G. W.;Staley, J. K.;Haber, S.;Mobley, C. J.;Miller, G. W.;Mufson, E. J.;Mash, D. C. \& Levey, A. I. (1999).Immunocytochemical localization of the dopamine transporter in human brain. J Comp Neurol, Vol.409, No.1, (Jun 21 1999), pp.(38-56), ISSN 0021-9967

Colbran, R. J.;Carmody, L. C.;Bauman, P. A.;Wadzinski, B. E. \& Bass, M. A. (2003).Analysis of specific interactions of native protein phosphatase 1 isoforms with targeting subunits. Methods Enzymol, Vol.366, 2003), pp.(156-175), ISSN 0076-6879

Del Negro, C. A.;Morgado-Valle, C.;Hayes, J. A.;Mackay, D. D.;Pace, R. W.;Crowder, E. A. \& Feldman, J. L. (2005).Sodium and calcium current-mediated pacemaker neurons and respiratory rhythm generation. J Neurosci, Vol.25, No.2, (Jan 12 2005), pp.(446453), ISSN 1529-2401

Dentresangle, C.;Le Cavorsin, M.;Savasta, M. \& Leviel, V. (2001).Increased extracellular DA and normal evoked DA release in the rat striatum after a partial lesion of the substantia nigra. Brain Res, Vol.893, No.1-2, (Mar 2 2001), pp.(178-185), ISSN 00068993

Descarries, L. \& Mechawar, N. (2000).Ultrastructural evidence for diffuse transmission by monoamine and acetylcholine neurons of the central nervous system. Prog Brain Res, Vol.125, 2000), pp.(27-47), ISSN 0079-6123

Desce, J. M.;Godeheu, G.;Galli, T.;Artaud, F.;Cheramy, A. \& Glowinski, J. (1992).Lglutamate-evoked release of dopamine from synaptosomes of the rat striatum: involvement of AMPA and N-methyl-D-aspartate receptors. Neuroscience, Vol.47, No.2, 1992), pp.(333-339), ISSN

Dzahini, K.;Dentresangle, C.;Le Cavorsin, M.;Bertrand, A.;Detraz, I.;Savasta, M. \& Leviel, V. (2010).Pre-synaptic glutamate-induced activation of DA release in the striatum after partial nigral lesion. J Neurochem, Vol.113, No.6, (Jun 2010), pp.(1459-1470), ISSN 1471-4159

Emmi, A.;Rajabi, H. \& Stewart, J. (1996).Behavioral and neurochemical recovery from partial 6-hydroxydopamine lesions of the substantia nigra is blocked by daily treatment with glutamate receptor antagonists MK-801 and CPP. J Neurosci, Vol.16, No.16, (Aug 15 1996), pp.(5216-5224), ISSN 0270-6474

Espino, A.;Cutillas, B.;Tortosa, A.;Ferrer, I.;Bartrons, R. \& Ambrosio, S. (1995).Chronic effects of single intrastriatal injections of 6-hydroxydopamine or 1-methyl-4phenylpyridinium studied by microdialysis in freely moving rats. Brain Res, Vol.695, No.2, (Oct 16 1995), pp.(151-157), ISSN 0006-8993

Ewing, A. G.;Bigelow, J. C. \& Wightman, R. M. (1983).Direct in vivo monitoring of dopamine released from two striatal compartments in the rat. Science, Vol.221, No.4606, (Jul 8 1983), pp.(169-171), ISSN 0036-8075

Ewing, A. G. \& Wightman, R. M. (1984).Monitoring the stimulated release of dopamine with in vivo voltammetry. II: Clearance of released dopamine from extracellular fluid. $J$ Neurochem, Vol.43, No.2, (Aug 1984), pp.(570-577), ISSN 0022-3042

Falkenburger, B. H.;Barstow, K. L. \& Mintz, I. M. (2001).Dendrodendritic inhibition through reversal of dopamine transport. Science, Vol.293, No.5539, (Sep 28 2001), pp.(24652470), ISSN 0036-8075

Fillenz, M. (1993).Short-term control of transmitter synthesis in central catecholaminergic neurones. Prog Biophys Mol Biol, Vol.60, No.1, 1993), pp.(29-46), ISSN 
Fischer, J. F. \& Cho, A. K. (1979).Chemical release of dopamine from striatal homogenates: evidence for an exchange diffusion model. J Pharmacol Exp Ther, Vol.208, No.2, (Feb 1979), pp.(203-209), ISSN 0022-3565

Fog, J. U.;Khoshbouei, H.;Holy, M.;Owens, W. A.;Vaegter, C. B.;Sen, N.;Nikandrova, Y.;Bowton, E.;McMahon, D. G.;Colbran, R. J.;Daws, L. C.;Sitte, H. H.;Javitch, J. A.;Galli, A. \& Gether, U. (2006).Calmodulin kinase II interacts with the dopamine transporter $C$ terminus to regulate amphetamine-induced reverse transport. Neuron, Vol.51, No.4, (Aug 17 2006), pp.(417-429), ISSN 0896-6273

Garcia, C.;Marcel, D.;Le Cavorsin, M.;Pujol, J. F. \& Weissmann, D. (1994).Phenotypic characteristics of expressed tyrosine hydroxylase protein in the adult rat nucleus tractus solitarius: plasticity revealed by RU24722 treatment. Neuroscience, Vol.62, No.4, (Oct 1994), pp.(1201-1205), ISSN 0306-4522

Gauthier, J.;Parent, M.;Levesque, M. \& Parent, A. (1999).The axonal arborization of single nigrostriatal neurons in rats. Brain Res, Vol.834, No.1-2, (Jul 10 1999), pp.(228-232), ISSN 0006-8993

Gerfen, C. R.;Herkenham, M. \& Thibault, J. (1987).The neostriatal mosaic: II. Patch- and matrix-directed mesostriatal dopaminergic and non-dopaminergic systems. J Neurosci, Vol.7, No.12, (Dec 1987), pp.(3915-3934), ISSN 0270-6474

Gerhardt, G. A.;Cass, W. A.;Hudson, J.;Henson, M.;Zhang, Z.;Ovadia, A.;Hoffer, B. J. \& Gash, D. M. (1996).In vivo electrochemical studies of dopamine overflow and clearance in the striatum of normal and MPTP-treated rhesus monkeys. J Neurochem, Vol.66, No.2, (Feb 1996), pp.(579-588), ISSN 0022-3042

Giorguieff, M. F.;Kemel, M. L. \& Glowinski, J. (1977).Presynaptic effect of L-glutamic acid on the release of dopamine in rat striatal slices. Neurosci Lett, Vol.6, No.1, (Oct 1977), pp.(73-77), ISSN 0304-3940

Gnegy, M. E.;Khoshbouei, H.;Berg, K. A.;Javitch, J. A.;Clarke, W. P.;Zhang, M. \& Galli, A. (2004).Intracellular Ca2+ regulates amphetamine-induced dopamine efflux and currents mediated by the human dopamine transporter. Mol Pharmacol, Vol.66, No.1, (Jul 2004), pp.(137-143), ISSN 0026-895X

Gonon, F. G. (1988).Nonlinear relationship between impulse flow and dopamine released by rat midbrain dopaminergic neurons as studied by in vivo electrochemistry. Neuroscience, Vol.24, No.1, (Jan 1988), pp.(19-28), ISSN 0306-4522

Gonon, F. G. \& Buda, M. J. (1985).Regulation of dopamine release by impulse flow and by autoreceptors as studied by in vivo voltammetry in the rat striatum. Neuroscience, Vol.14, No.3, (Mar 1985), pp.(765-774), ISSN 0306-4522

Gonon, F. G.;Navarre, F. \& Buda, M. J. (1984).In vivo monitoring of dopamine release in the rat brain with differential normal pulse voltammetry. Anal Chem, Vol.56, No.3, (Mar 1984), pp.(573-575), ISSN 0003-2700

Grace, A. A. (1991).Phasic versus tonic dopamine release and the modulation of dopamine system responsivity: a hypothesis for the etiology of schizophrenia. Neuroscience, Vol.41, No.1, 1991), pp.(1-24), ISSN 0306-4522

Grace, A. A. (2008).Physiology of the normal and dopamine-depleted basal ganglia: insights into levodopa pharmacotherapy. Mov Disord, Vol.23 Suppl 3, 2008), pp.(S560-569), ISSN 1531-8257 
Greenamyre, J. T. \& O'Brien, C. F. (1991).N-methyl-D-aspartate antagonists in the treatment of Parkinson's disease. Arch Neurol, Vol.48, No.9, (Sep 1991), pp.(977-981), ISSN 0003-9942

Griffith, L. C. (2004).Regulation of calcium/calmodulin-dependent protein kinase II activation by intramolecular and intermolecular interactions. J Neurosci, Vol.24, No.39, (Sep 29 2004), pp.(8394-8398), ISSN 1529-2401

Harden, D. G. \& Grace, A. A. (1995).Activation of dopamine cell firing by repeated L-DOPA administration to dopamine-depleted rats: its potential role in mediating the therapeutic response to L-DOPA treatment. J Neurosci, Vol.15, No.9, (Sep 1995), pp.(6157-6166), ISSN 0270-6474

Haycock, J. W. (1993).Multiple signaling pathways in bovine chromaffin cells regulate tyrosine hydroxylase phosphorylation at Ser19, Ser31, and Ser40. Neurochem Res, Vol.18, No.1, (Jan 1993), pp.(15-26), ISSN 0364-3190

Hefti, F.;Enz, A. \& Melamed, E. (1985).Partial lesions of the nigrostriatal pathway in the rat. Acceleration of transmitter synthesis and release of surviving dopaminergic neurones by drugs. Neuropharmacology, Vol.24, No.1, (Jan 1985), pp.(19-23), ISSN 0028-3908

Herdon, H.;Strupish, J. \& Nahorski, S. R. (1985).Differences between the release of radiolabelled and endogenous dopamine from superfused rat brain slices: effects of depolarizing stimuli, amphetamine and synthesis inhibition. Brain Res, Vol.348, No.2, (Dec 2 1985), pp.(309-320), ISSN 0006-8993

Hollerman, J. R. \& Grace, A. A. (1990).The effects of dopamine-depleting brain lesions on the electrophysiological activity of rat substantia nigra dopamine neurons. Brain Res, Vol.533, No.2, (Nov 19 1990), pp.(203-212), ISSN 0006-8993

Iversen, S. D. \& Iversen, L. L. (2007).Dopamine: 50 years in perspective. Trends Neurosci, Vol.30, No.5, (May 2007), pp.(188-193), ISSN 0166-2236

Iwasaki, Y.;Ikeda, K.;Shiojima, T. \& Kinoshita, M. (1992).Increased plasma concentrations of aspartate, glutamate and glycine in Parkinson's disease. Neurosci Lett, Vol.145, No.2, (Oct 12 1992), pp.(175-177), ISSN 0304-3940

Jhamandas, K. \& Marien, M. (1987).Glutamate-evoked release of endogenous brain dopamine: inhibition by an excitatory amino acid antagonist and an enkephalin analogue. Br J Pharmacol, Vol.90, No.4, (Apr 1987), pp.(641-650), ISSN 0007-1188

Kantor, L.;Hewlett, G. H.;Park, Y. H.;Richardson-Burns, S. M.;Mellon, M. J. \& Gnegy, M. E. (2001).Protein kinase $C$ and intracellular calcium are required for amphetaminemediated dopamine release via the norepinephrine transporter in undifferentiated PC12 cells. J Pharmacol Exp Ther, Vol.297, No.3, (Jun 2001), pp.(1016-1024), ISSN 0022-3565

Kapatos, G. \& Zigmond, M. J. (1982).Influence of calcium on dopamine synthesis and tyrosine hydroxylase activity in rat striatum. J Neurochem, Vol.39, No.2, (Aug 1982), pp.(327-335), ISSN 0022-3042

Kashani, A.;Betancur, C.;Giros, B.;Hirsch, E. \& El Mestikawy, S. (2007).Altered expression of vesicular glutamate transporters VGLUT1 and VGLUT2 in Parkinson disease. Neurobiol Aging, Vol.28, No.4, (Apr 2007), pp.(568-578), ISSN 1558-1497

Katz, B. \& Miledi, R. (1970).Further study of the role of calcium in synaptic transmission. J Physiol, Vol.207, No.3, (May 1970), pp.(789-801), ISSN 0022-3751 
Keefe, K. A.;Zigmond, M. J. \& Abercrombie, E. D. (1992).Extracellular dopamine in striatum: influence of nerve impulse activity in medial forebrain bundle and local glutamatergic input. Neuroscience, Vol.47, No.2, 1992), pp.(325-332), ISSN 0306-4522

Keefe, K. A.;Zigmond, M. J. \& Abercrombie, E. D. (1993).In vivo regulation of extracellular dopamine in the neostriatum: influence of impulse activity and local excitatory amino acids. J Neural Transm Gen Sect, Vol.91, No.2-3, 1993), pp.(223-240), ISSN 0300-9564

Khoshbouei, H.;Wang, H.;Lechleiter, J. D.;Javitch, J. A. \& Galli, A. (2003).Amphetamineinduced dopamine efflux. A voltage-sensitive and intracellular Na+-dependent mechanism. J Biol Chem, Vol.278, No.14, (Apr 4 2003), pp.(12070-12077), ISSN 00219258

Lavergne, A.;Frain, O.;Guibert, B.;Biguet, N. F. \& Leviel, V. (1994).Regulation of tyrosine hydroxylase gene expression in mesencephalic dopamine neurons: effect of imipramine treatment. Neurosci Lett, Vol.182, No.2, (Dec 5 1994), pp.(167-171), ISSN 0304-3940

Leslie, S. W.;Chandler, L. J.;Barr, E. M. \& Farrar, R. P. (1985).Reduced calcium uptake by rat brain mitochondria and synaptosomes in response to aging. Brain Res, Vol.329, No.1-2, (Mar 11 1985), pp.(177-183), ISSN 0006-8993

Levi, G. \& Raiteri, M. (1993).Carrier-mediated release of neurotransmitters. Trends Neurosci, Vol.16, No.10, (Oct 1993), pp.(415-419), ISSN 0166-2236

Leviel, V. (2001).The reverse transport of DA, what physiological significance? Neurochem Int, Vol.38, No.2, (Feb 2001), pp.(83-106), ISSN

Leviel, V.;Fayada, C.;Guibert, B.;Chaminade, M.;Machek, G.;Mallet, J. \& Biguet, N. F. (1990).Short- and long-term alterations of gene expression in limbic structures by repeated electroconvulsive-induced seizures. J Neurochem, Vol.54, No.3, (Mar 1990), pp.(899-904), ISSN 0022-3042

Leviel, V.;Gobert, A. \& Guibert, B. (1989).Direct observation of dopamine compartmentation in striatal nerve terminal by 'in vivo' measurement of the specific activity of released dopamine. Brain Res, Vol.499, No.2, (Oct 16 1989), pp.(205-213), ISSN

Levitt, M.;Spector, S.;Sjoerdsma, A. \& Udenfriend, S. (1965).Elucidation of the Rate-Limiting Step in Norepinephrine Biosynthesis in the Perfused Guinea-Pig Heart. J Pharmacol Exp Ther, Vol.148, (Apr 1965), pp.(1-8), ISSN 0022-3565

Liang, N. Y. \& Rutledge, C. O. (1982).Evidence for carrier-mediated efflux of dopamine from corpus striatum. Biochem Pharmacol, Vol.31, No.15, (Aug 1 1982), pp.(2479-2484), ISSN 0006-2952

Lin, A. M. \& Chai, C. Y. (1998).Role of dopamine uptake in NMDA-modulated K(+)-evoked dopamine overflow in rat striatum: an in vivo electrochemical study. Neurosci Res, Vol.31, No.3, (Jul 1998), pp.(171-177), ISSN 0168-0102

Lindefors, N. \& Ungerstedt, U. (1990).Bilateral regulation of glutamate tissue and extracellular levels in caudate-putamen by midbrain dopamine neurons. Neurosci Lett, Vol.115, No.2-3, (Jul 31 1990), pp.(248-252), ISSN 0304-3940

Lipscombe, D.;Madison, D. V.;Poenie, M.;Reuter, H.;Tsien, R. Y. \& Tsien, R. W. (1988).Spatial distribution of calcium channels and cytosolic calcium transients in growth cones and cell bodies of sympathetic neurons. Proc Natl Acad Sci U $S$ A, Vol.85, No.7, (Apr 1988), pp.(2398-2402), ISSN 0027-8424 
Maloteaux, J. M.;Vanisberg, M. A.;Laterre, C.;Javoy-Agid, F.;Agid, Y. \& Laduron, P. M. (1988).[3H]GBR 12935 binding to dopamine uptake sites: subcellular localization and reduction in Parkinson's disease and progressive supranuclear palsy. Eur J Pharmacol, Vol.156, No.3, (Nov 8 1988), pp.(331-340), ISSN 0014-2999

Mann, S. P. \& Bennett, R. C. (1979).The fate of choline in the circulating plasma of the rat. Experientia, Vol.35, No.2, (Feb 15 1979), pp.(211-212), ISSN 0014-4754

Mantz, J.;Cheramy, A.;Thierry, A. M.;Glowinski, J. \& Desmonts, J. M. (1992).Anesthetic properties of riluzole (54274 RP), a new inhibitor of glutamate neurotransmission. Anesthesiology, Vol.76, No.5, (May 1992), pp.(844-848), ISSN 0003-3022

Marchi, M.;Paudice, P.;Bonanno, G. \& Raiteri, M. (1985).Presynaptic muscarinic receptor activation enhances striatal dopamine release evoked by depolarization but not that induced by non-depolarizing stimuli. Neurochem Int, Vol.7, No.1, 1985), pp.(137141), ISSN 0197-0186

Masserano, J. M.;Venable, D. \& Wyatt, R. J. (1994).Effects of chronic cocaine administration on $[3 \mathrm{H}]$ dopamine uptake in the nucleus accumbens, striatum and frontal cortex of rats. J Pharmacol Exp Ther, Vol.270, No.1, (Jul 1994), pp.(133-141), ISSN 0022-3565

Meldolesi, J.;Volpe, P. \& Pozzan, T. (1988).The intracellular distribution of calcium. Trends Neurosci, Vol.11, No.10, (Oct 1988), pp.(449-452), ISSN 0166-2236

Mengual, E. \& Pickel, V. M. (2004).Regional and subcellular compartmentation of the dopamine transporter and tyrosine hydroxylase in the rat ventral pallidum. Journal of Comparative Neurology, Vol.468, No.3, 2004), pp.(395-409), ISSN

Miller, R. J. (1991).The control of neuronal Ca2+ homeostasis. Prog Neurobiol, Vol.37, No.3, 1991), pp.(255-285), ISSN 0301-0082

Nash, J. F. \& Brodkin, J. (1991). Microdialysis studies on 3,4methylenedioxymethamphetamine-induced dopamine release: effect of dopamine uptake inhibitors. J Pharmacol Exp Ther, Vol.259, No.2, (Nov 1991), pp.(820-825), ISSN 0022-3565

Nirenberg, M. J.;Vaughan, R. A.;Uhl, G. R.;Kuhar, M. J. \& Pickel, V. M. (1996).The dopamine transporter is localized to dendritic and axonal plasma membranes of nigrostriatal dopaminergic neurons. J Neurosci, Vol.16, No.2, (Jan 15 1996), pp.(436-447), ISSN

Okada, M.;Mine, K. \& Fujiwara, M. (1990).The $\mathrm{Na}(+)$-dependent release of endogenous dopamine and noradrenaline from rat brain synaptosomes. J Pharmacol Exp Ther, Vol.252, No.3, (Mar 1990), pp.(1283-1288), ISSN 0022-3565

Olivier, V.;Gobert, A.;Guibert, B. \& Leviel, V. (1999).The in vivo modulation of dopamine synthesis by calcium ions: influences on the calcium independent release. Neurochem Int, Vol.35, No.6, (Dec 1999), pp.(431-438), ISSN 0197-0186

Olivier, V.;Guibert, B. \& Leviel, V. (1995).Direct in vivo comparison of two mechanisms releasing dopamine in the rat striatum. Brain Res, Vol.695, No.1, (Oct 9 1995), pp.(19), ISSN

Opazo, F.;Schulz, J. B. \& Falkenburger, B. H. (2010).PKC links Gq-coupled receptors to DATmediated dopamine release. J Neurochem, Vol.114, No.2, (Jul 2010), pp.(587-596), ISSN 1471-4159

Pal, R.;Nath, R. \& Gill, K. D. (1993).Influence of ethanol on cadmium accumulation and its impact on lipid peroxidation and membrane bound functional enzymes ( $\mathrm{Na}+$, $\mathrm{K}(+)$-ATPase and acetylcholinesterase) in various regions of adult rat brain. Neurochem Int, Vol.23, No.5, (Nov 1993), pp.(451-458), ISSN 0197-0186 
Papa, S. M.;Boldry, R. C.;Engber, T. M.;Kask, A. M. \& Chase, T. N. (1995).Reversal of levodopa-induced motor fluctuations in experimental parkinsonism by NMDA receptor blockade. Brain Res, Vol.701, No.1-2, (Dec 1 1995), pp.(13-18), ISSN 00068993

Parker, E. M. \& Cubeddu, L. X. (1986).Effects of d-amphetamine and dopamine synthesis inhibitors on dopamine and acetylcholine neurotransmission in the striatum. II. Release in the presence of vesicular transmitter stores. J Pharmacol Exp Ther, Vol.237, No.1, (Apr 1986), pp.(193-203), ISSN 0022-3565

Pasinetti, G. M.;Lerner, S. P.;Johnson, S. A.;Morgan, D. G.;Telford, N. A. \& Finch, C. E. (1989).Chronic lesions differentially decrease tyrosine hydroxylase messenger RNA in dopaminergic neurons of the substantia nigra. Brain Res Mol Brain Res, Vol.5, No.3, (May 1989), pp.(203-209), ISSN 0169-328X

Paton, D. M. (1973).Evidence for carrier-mediated efflux of noradrenaline from the axoplasm of adrenergic nerves in rabbit atria. J Pharm Pharmacol, Vol.25, No.3, (Mar 1973), pp.(265-267), ISSN 0022-3573

Paton, D. M. (1973).Mechanism of efflux of noradrenaline from adrenergic nerves in rabbit atria. Br J Pharmacol, Vol.49, No.4, (Dec 1973), pp.(614-627), ISSN 0007-1188

Perez, X. A.;Parameswaran, N.;Huang, L. Z.;O'Leary, K. T. \& Quik, M. (2008).Pre-synaptic dopaminergic compensation after moderate nigrostriatal damage in non-human primates. J Neurochem, Vol.105, No.5, (Jun 2008), pp.(1861-1872), ISSN 1471-4159

Phillips, J. M.;Lam, H. A.;Ackerson, L. C. \& Maidment, N. T. (2006).Blockade of mGluR glutamate receptors in the subthalamic nucleus ameliorates motor asymmetry in an animal model of Parkinson's disease. Eur J Neurosci, Vol.23, No.1, (Jan 2006), pp.(151-160), ISSN 0953-816X

Prensa, L.;Cossette, M. \& Parent, A. (2000).Dopaminergic innervation of human basal ganglia. J Chem Neuroanat, Vol.20, No.3-4, (Dec 2000), pp.(207-213), ISSN 0891-0618

Raiteri, M.;Cerrito, F.;Cervoni, A. M. \& Levi, G. (1979).Dopamine can be released by two mechanisms differentially affected by the dopamine transport inhibitor nomifensine. J Pharmacol Exp Ther, Vol.208, No.2, (Feb 1979), pp.(195-202), ISSN 0022-3565

Raiteri, M.;del Carmine, R. \& Bertollini, A. (1977).Effect of desmethylimipramine on the release of $(3 \mathrm{H})$ norepinephrine induced by various agents in hypothalamic synaptosomes. Mol Pharmacol, Vol.13, No.4, (Jul 1977), pp.(746-758), ISSN 0026-895X

Robinson, T. E. \& Whishaw, I. Q. (1988).Normalization of extracellular dopamine in striatum following recovery from a partial unilateral 6-OHDA lesion of the substantia nigra: a microdialysis study in freely moving rats. Brain Res, Vol.450, No.1-2, (May 31 1988), pp.(209-224), ISSN 0006-8993

Romo, R.;Cheramy, A.;Godeheu, G. \& Glowinski, J. (1986).In vivo presynaptic control of dopamine release in the cat caudate nucleus--III. Further evidence for the implication of corticostriatal glutamatergic neurons. Neuroscience, Vol.19, No.4, (Dec 1986), pp.(1091-1099), ISSN 0306-4522

Samuel, D.;Errami, M. \& Nieoullon, A. (1990).Localization of N-methyl-D-aspartate receptors in the rat striatum: effects of specific lesions on the $[3 \mathrm{H}] 3-(2-$ carboxypiperazin-4-yl)propyl-1-phosphonic acid binding. J Neurochem, Vol.54, No.6, (Jun 1990), pp.(1926-1933), ISSN 0022-3042 
Sesack, S. R.;Hawrylak, V. A.;Matus, C.;Guido, M. A. \& Levey, A. I. (1998).Dopamine axon varicosities in the prelimbic division of the rat prefrontal cortex exhibit sparse immunoreactivity for the dopamine transporter. J Neurosci, Vol.18, No.7, (Apr 1 1998), pp.(2697-2708), ISSN 0270-6474

Snyder, G. L.;Keller, R. W., Jr. \& Zigmond, M. J. (1990).Dopamine efflux from striatal slices after intracerebral 6-hydroxydopamine: evidence for compensatory hyperactivity of residual terminals. J Pharmacol Exp Ther, Vol.253, No.2, (May 1990), pp.(867-876), ISSN 0022-3565

Soares-da-Silva, P. (1987).Does brain 3,4-dihydroxyphenylacetic acid reflect dopamine release? J Pharm Pharmacol, Vol.39, No.2, (Feb 1987), pp.(127-129), ISSN 0022-3573

Sonsalla, P. K.;Nicklas, W. J. \& Heikkila, R. E. (1989).Role for excitatory amino acids in methamphetamine-induced nigrostriatal dopaminergic toxicity. Science, Vol.243, No.4889, (Jan 20 1989), pp.(398-400), ISSN 0036-8075

Stachowiak, M. K.;Keller, R. W., Jr.;Stricker, E. M. \& Zigmond, M. J. (1987).Increased dopamine efflux from striatal slices during development and after nigrostriatal bundle damage. J Neurosci, Vol.7, No.6, (Jun 1987), pp.(1648-1654), ISSN 0270-6474

Stein, W. (1967). The movements of molecules across cell membranes, Academic Press, New York, USA

Stein, W.(1990). Channels, carriers and pumps: an introduction to the membrane transport, Academic Press, New York, USA

Suaud Chagn, Y. M. F.;Brun, P.;Buda, M. \& Gonon, F. Fast in vivo monitoring of electrically evoked doPamine release by differential pulse amperometry with untreated carbon fibre electrodes. J Neurosci Methods, Vol.45, No.3, pp.(183-190), ISSN

Tang, K.;Low, M. J.;Grandy, D. K. \& Lovinger, D. M. (2001).Dopamine-dependent synaptic plasticity in striatum during in vivo development. Proc Natl Acad Sci U S A, Vol.98, No.3, (Jan 30 2001), pp.(1255-1260), ISSN 0027-8424

Thoenen, H.;Huerlimann, A. \& Haefely, W. (1969).Cation dependence of the noradrenalinereleasing action of tyramine. Eur J Pharmacol, Vol.6, No.1, (Apr 1969), pp.(29-37), ISSN 0014-2999

Turski, L.;Bressler, K.;Rettig, K. J.;Loschmann, P. A. \& Wachtel, H. (1991).Protection of substantia nigra from MPP+ neurotoxicity by N-methyl-D-aspartate antagonists. Nature, Vol.349, No.6308, (Jan 31 1991), pp.(414-418), ISSN 0028-0836

van Horne, C.;Hoffer, B. J.;Stromberg, I. \& Gerhardt, G. A. (1992).Clearance and diffusion of locally applied dopamine in normal and 6-hydroxydopamine-lesioned rat striatum. J Pharmacol Exp Ther, Vol.263, No.3, (Dec 1992), pp.(1285-1292), ISSN 0022-3565

Vizi, E. S. \& Labos, E. (1991).Non-synaptic interactions at presynaptic level. Prog Neurobiol, Vol.37, No.2, 1991), pp.(145-163), ISSN 0301-0082

Vrana, K. E. \& Roskoski, R., Jr. (1983).Tyrosine hydroxylase inactivation following cAMPdependent phosphorylation activation. J Neurochem, Vol.40, No.6, (Jun 1983), pp.(1692-1700), ISSN 0022-3042

Westerink, B. H.;Hofsteede, H. M.;Damsma, G. \& de Vries, J. B. (1988).The significance of extracellular calcium for the release of dopamine, acetylcholine and amino acids in conscious rats, evaluated by brain microdialysis. Naunyn Schmiedebergs Arch Pharmacol, Vol.337, No.4, (Apr 1988), pp.(373-378), ISSN 0028-1298 
Wheeler, D. D.;Edwards, A. M.;Chapman, B. M. \& Ondo, J. G. (1993).A model of the sodium dependence of dopamine uptake in rat striatal synaptosomes. Neurochem Res, Vol.18, No.8, (Aug 1993), pp.(927-936), ISSN 0364-3190

Wilson, C. J. (1995).Dynamic modification of dendritic cable properties and synaptic transmission by voltage-gated potassium channels. J Comput Neurosci, Vol.2, No.2, (Jun 1995), pp.(91-115), ISSN 0929-5313

Wullner, U.;Standaert, D. G.;Testa, C. M.;Landwehrmeyer, G. B.;Catania, M. V.;Penney, J. B., Jr. \& Young, A. B. (1994).Glutamate receptor expression in rat striatum: effect of deafferentation. Brain Res, Vol.647, No.2, (Jun 6 1994), pp.(209-219), ISSN 0006-8993

Zahniser, N. R.;Gerhardt, G. A.;Hoffman, A. F. \& Lupica, C. R. (1998).Voltage-dependency of the dopamine transporter in rat brain. Adv Pharmacol, Vol.42, 1998), pp.(195-198), ISSN 1054-3589

Zetterstrom, T.;Sharp, T.;Collin, A. K. \& Ungerstedt, U. (1988).In vivo measurement of extracellular dopamine and DOPAC in rat striatum after various dopaminereleasing drugs; implications for the origin of extracellular DOPAC. Eur J Pharmacol, Vol.148, No.3, (Apr 13 1988), pp.(327-334), ISSN 0014-2999

Ziance, R. J. \& Rutledge, C. O. (1972).A comparison of the effects of fenfluramine and amphetamine on uptake release and catabolism of norepinephrine in rat brain. $J$ Pharmacol Exp Ther, Vol.180, No.1, (Jan 1972), pp.(118-126), ISSN 0022-3565

Zigmond, M. J.;Abercrombie, E. D.;Berger, T. W.;Grace, A. A. \& Stricker, E. M. (1990).Compensations after lesions of central dopaminergic neurons: some clinical and basic implications. Trends Neurosci., Vol.13, No.7, 1990), pp.(296), ISSN

Zigmond, M. J.;Acheson, A. L.;Stachowiak, M. K. \& Stricker, E. M. (1984).Neurochemical compensation after nigrostriatal bundle injury in an animal model of preclinical parkinsonism. Arch Neurol, Vol.41, No.8, (Aug 1984), pp.(856-861), ISSN 0003-9942

Zigmond, M. J.;Berger, T. W.;Grace, A. A. \& Stricker, E. M. (1989).Compensatory responses to nigrostriatal bundle injury. Studies with 6-hydroxydopamine in an animal model of parkinsonism. Mol Chem Neuropathol, Vol.10, No.3, (Jun 1989), pp.(185200), ISSN 1044-7393

Zucker, R. S. \& Lando, L. (1986).Mechanism of transmitter release: voltage hypothesis and calcium hypothesis. Science, Vol.231, No.4738, (Feb 7 1986), pp.(574-579), ISSN 00368075 


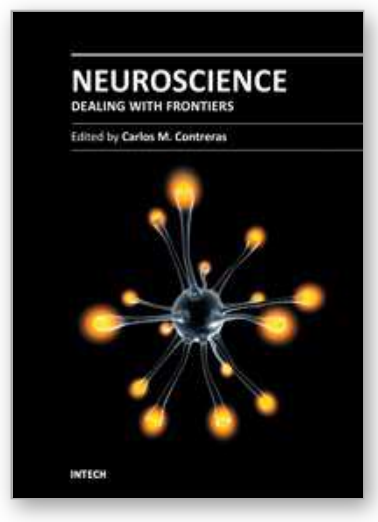

\author{
Neuroscience - Dealing With Frontiers \\ Edited by Dr. Carlos M. Contreras
}

ISBN 978-953-51-0207-6

Hard cover, 440 pages

Publisher InTech

Published online 16, March, 2012

Published in print edition March, 2012

The Neuronal Doctrine recently reached its 100th year and together with the development of psychopharmacology by the middle of 20th century promoted spectacular developments in the knowledge of the biological bases of behavior. The overwhelming amount of data accumulated, forced the division of neuroscience into several subdisciplines, but this division needs to dissolve in the 21 st century and focus on specific processes that involve diverse methodological and theoretical approaches. The chapters contained in this book illustrate that neuroscience converges in the search for sound answers to several questions, including the pathways followed by cells, how individuals communicate with each other, inflammation, learning and memory, the development of drug dependence, and approaches to explaining the processes that underlie two highly incapacitating chronic degenerative illnesses.

\title{
How to reference
}

In order to correctly reference this scholarly work, feel free to copy and paste the following:

Vincent Leviel, Alain Gobert, Valérie Olivier, Christine Dentresangle, Wadad Hassoun and Kwamivi Dzahini (2012). Normal and Physio-Pathological Striatal Dopamine Homeostasis, Neuroscience - Dealing With Frontiers, Dr. Carlos M. Contreras (Ed.), ISBN: 978-953-51-0207-6, InTech, Available from: http://www.intechopen.com/books/neuroscience-dealing-with-frontiers/normal-and-physio-pathological-striataldopamine-homeostasis-

\section{INTECH}

open science | open minds

\section{InTech Europe}

University Campus STeP Ri

Slavka Krautzeka 83/A

51000 Rijeka, Croatia

Phone: +385 (51) 770447

Fax: +385 (51) 686166

www.intechopen.com

\section{InTech China}

Unit 405, Office Block, Hotel Equatorial Shanghai No.65, Yan An Road (West), Shanghai, 200040, China 中国上海市延安西路65号上海国际贵都大饭店办公楼 405 单元 Phone: +86-21-62489820

Fax: $+86-21-62489821$ 
(C) 2012 The Author(s). Licensee IntechOpen. This is an open access article distributed under the terms of the Creative Commons Attribution 3.0 License, which permits unrestricted use, distribution, and reproduction in any medium, provided the original work is properly cited. 